\title{
Religious Debate and Visual Compromise: Interpreting Byzantine Murals in Lithuania and Poland
}

Giedrè Mickūnaitè / giedre.mickunaite@vda.lt

Vilniaus dailès akademija (Vilnius Academy of Arts), Vilnius, LT

\begin{abstract}
The Byzantine-style murals which adorned the interiors of Lithuanian castles and churches and were "exported" to Poland during King Wladislas II's reign are regarded as reflecting religious debates. This discussion highlights the Orthodox and Catholic interference in the display and iconography of these wall paintings and constructs hypothetical roles for those who commissioned, painted and supervised the content of the interior decoration. From the late fourteenth century, attitudes towards these paintings changed over a hundred years: from passivity towards their content, to religious alterations either by Orthodox masters or by Catholic patrons or supervisors, and ended with the murals being labelled as the style of the Jagiellonian house.
\end{abstract}

\section{Keywords}

Wall Paintings; Iconography; Style; Religion; Catholic Confession; Orthodox Confession 


\section{Introduction}

The well-known scholarly dictum about the Grand Duchy of Lithuania being a meeting point and melting pot of Eastern and Western Christian traditions has its visual elements. From the late fourteenth century, the residential quarters of grand ducal castles were decorated with Byzantine murals, which also embellished interiors of Catholic churches after the country's conversion in 1387. There are no surviving written documents about these paintings, which have reached us as fragments, copies or excavated debris.

This research attempts to overcome the absence of medieval records by constructing a narrative of the religious or confessional differences as revealed in (or projected onto) the painted walls. This essay, therefore, provides roles for the pagan and then Catholic patrons, hypothetical clerics, who supervised the painters and altered the mural decorations; and the largely anonymous Orthodox masters working across the religious divide. The sources and historical traditions provide the names of some of the patrons, but do not reveal their motives or how these Byzantine murals were viewed at the time. Therefore, these roles ascribe typical religious characteristics based on the premise that every actor observed differences in status and confession. The three parts of this essay discuss the attitudes towards Byzantine murals before Lithuania's Catholic conversion in 1387, the confessionalization of these paintings at the beginning of the fifteenth century, and the end of this artistic practice towards the end of the century.

\section{Faithful for the faithless}

The wall paintings which once adorned the residential quarters of the castles in Kreva, Medininkai and Vilnius have survived as archaeological debris. This section attempts to place the excavated pieces into a historical narrative constructed along the lines of religious differences.

The grand ducal seat in Vilnius ${ }^{1}$ was surrounded by a number of brick fortresses, the interiors of which, with a few exceptions, were decorated with Byzantine-style murals. The castles at Kreva, Medininkai, and Lida guarded Vilnius from the south. Located at a distance of around $50 \mathrm{~km}$ from each other and the Lithuanian capital, the three forts are of very similar architecture, consisting of rectangular red-brick walls and several towers, one of which contained residential quarters. In Kreva and Medininkai, the interiors of these towers had been painted with murals which were never mentioned in the historical records and were thus almost ignored by scholars. The castle at Kreva is also famous as the site of controversial and decisive political events in the history of the grand ducal family and consequently for Lithuanian history as a whole. Inherited by Grand Duke Jogaila (c. 1350-1434) as his paternal share in 1377, the castle gained

1 Due to its very fragmentary state, the decoration of the Lower Castle of Vilnius with Byzantine murals has been left out of this discussion. 
notoriety as the place where Jogaila's uncle Kęstutis (reign 1381-1382) was strangled and where his cousin Vytautas (c. 1350-1430) was incarcerated in 1382. It was in Kreva that Jogaila signed the agreement of conversion to the Catholic faith, marrying Queen Hedwig (1373-1399), and becoming king of Poland in 1385 and $1386 .{ }^{2}$ From the late fifteenth century, the castle lost its function and was gradually abandoned; ${ }^{3}$ however, the building survived in relatively good shape until World War I. As with many other historical monuments, the castle was "discovered" in the nineteenth century and some visitors even mentioned its decorated interior and ornamental paintings with their unevenly shaped crosses. ${ }^{4}$ During World War I, regiments from the German army used the castle as a stronghold, which was bombed during a Russian attack from 19 to 21 July $1917 .{ }^{5}$ In 1929, the surviving walls were preserved and prevented from collapsing. ${ }^{6}$ This conservation work provided information about the paintings; however, they received no scholarly attention. $^{7}$ The "discovery" of the murals occurred during archaeological excavations undertaken in $1988^{8}$ and $2012 .^{9}$

In contrast to Kreva, the castle at Medininkai had been absent in the records since the Middle Ages. First documented in the 1320s, the castle was used for defensive and

2 For the treaty of Kreva and its context, see $1385 \mathrm{~m}$. rugpjūčio 14 d. Krévos aktas. Ed. Jūratè Kiaupienè. Lietuvos užsienio politikos dokumentai XIII-XVIII a. Vilnius 2002.

3 In 1517, an envoy of the Holy Roman Empire, Sigismund von Herberstein (1486-1566), wrote of Kreva: Crevua oppidum cum castro deserto / gehn Crewa da ist ain ödes gemeuer aines gewesnen Schlo $\beta$, see in HERBERSTEIN, Sigismund von: Rerum Moscoviticarum Commentarii. Synoptische Edition der lateinischen und der deutschen Fassung letzter Hand Basel 1556 und Wien 1557. Unter der Leitung von Frank Kämpfer erstellt von Eva Maurer und Andreas Fülberth. Hg. v. Hermann Beyer-Thoma. München 2007, p. 464:18 and p. 464:56.

4 Nieco jest potynkowane i upiękrzone, see in W.F.K. Do JP. Redaktora Tygodnika Wileńskiego z Bieniun Roku 1816. dnia 27 Maja v.s. Tygodnik Wileński 3.62 (21/01/1817), p. 139 'Papiery po Adamie Kirkorze. Materiały i prace innych osób, pochodzące z okresu wileńskiego A. Kirkora’, vol. 3b, Library of the Jagiellonian University, Manuscript Department, BJ 4497, 1a, 'Opisanie rozvalin Starinnogo Zamka v kazennom miastechke Krev, otstoyashchem ot Uezdnogo Goroda Oshmiany v 20-i verstakh, o ot Gubernskaga Goroda Vil'ny v 78-i. Sostavlennoe Oktiabria 31 dnia 1838 g.', fol. 35. 'W 1843 r. w baszcie Zamku widzieć można było ślady dwójga schodów na piętra niegdyś wiodących i na ścianach malowidla wyobrażające liście w kształt krzyżów nieforemnych ułożone', Zieńkiewicz, Romuald: O kurhanach i grodziskach Powiatu Oszmiańskiego. Athenaeum 5, 1848, p. 126; I am grateful to Dr. Aleg Dziarnovich for the references in the periodicals.

5 Дзярновгч, Алег И.: Страты матэрыяльнай гісторыка-культурнай спадчыны ў гады Першай сусветнай вайны: на прыкладзе Крэускага замка. In: Знакамітыя мінчане. Мінск і Міншчына ў гады Першай сусветанй вайны: людзі і вайна. Матэрыялы VII беларуска-польскай навукова-тэарэтычнай канферэнцыі: Мінск. 9-10 красавіка 2014 г. Minsk 2015, pp. 118-120.

6 Lorentz, Stanisław: Konserwacja ruin zamków w Wileńszczyżnie i Nowogródczyżnie. Ochrona zabytków sztuki. Czasopismo poświęcone opiece nad zabytkami, inwentaryzacji i geografii zabytków. Zeszyt 1/4, część 1, 1930/1931, pp. 161-179.

7 The existence of the paintings is mentioned in AdOMONIS, Tadas - ČERBULĖNAS, Klemensas: Lietuvos TSR dailes ir architektūros istorija. Vol. 1: Nuo seniausiu laiku iki 1775 metu. Vilnius 1987, p. 77.

8 Ткачев, Михаил А. - Трусов, Олег А.: Исторические и архитектурно-археологические исследования Кревского замка. Lietuvos TSR architekturos klausimai 9/1, 1988, pp. 3-22; ЧАРняўскі, Ігар - ЦэйтлінА, Марына: Архітэктурна-мастачкія асаблівасиі Крәускага замка. In: Каштоўнасці мінуўшчыны. Vol. 4. Помнікі археалогіi: праблемы аховы і вывучэння: Матәрыялы канферэнцыі. Minsk 2001, pp. 97-103.

9 Дзярновгч, Алег - Мцкунайтэ, Гедра: Сценапіс Крэускага замка: выяуленне $i$ культурны кантэкст помніка манументальнага жывапісу. Беларускі гістарычны часопіс 2017/4, pp. 1-16. 
residential purposes until the end of the fifteenth century. The last reference to its grand ducal service is from January 1495, when Helena of Muscovy stayed there before travelling to Vilnius to marry Grand Duke Alexander. ${ }^{10}$ The historiography and iconography of Medininkai Castle is surprisingly poor. Most of the castle's descriptions and visitors' impressions published in periodicals and guidebooks from the nineteenth century are projections of a "great" past onto the mute ruins.

Close both in terms of location and architecture, the castles at Kreva and Medininkai were also decorated with similar murals. Among the finds from both castles are curved pieces of plaster containing fragments of $\mathrm{V}$ - and plait-shaped ornaments that once must have marked the vaulting ribs, and ornamental pieces distinguished by thick white dots that adorned the walls (Figs. 1, 2 and 5, 6). Fragments of human faces and heads (Figs. 3,4 and 7,8 ) testify to some figurative compositions; unfortunately, it is impossible to ascertain their content. Therefore, I have established the "cultural coordinates" of these murals on the basis of their painting techniques, rather than unknown subject matter. The plastered interiors were smoothened by fine base plaster, which was entirely covered with chalk-based white paint. On top of this layer, ornaments and figures were painted $a l$ secco with shades of umber, brown, and ochre. Contours and "shadows" were marked by adding ground charcoal into the main colour. The decoration was finished using thick dots and strokes of white paint. All the above-listed features are similar to the characteristics of the so-called Pskov School of Old Russian art, ${ }^{11}$ best represented by the frescoes in the monastery of Snetogorsk (1313 and later). ${ }^{12}$ Archaeological explorations in the Dovmont-gorod area of Pskov revealed that these principles survived into the fifteenth century, regardless of the al secco technique becoming widespread..$^{13}$ Interestingly, fragments of medieval wall paintings recently excavated in Tver' also display "Pskovian" features. ${ }^{14}$ Apparently, light backgrounds (sometimes even leaving the plaster unpainted),

10 Сборник Императорского Русского Исторического Общества. Вол. 35. Памятники дипломатических сношений Древней России с державами иностранными. Sankt Peterburg 1882, Ho. 35.I, p. 185. On the marriage, see MickūNaItÉ, Giedrè: United in blood, divided by faith: Elena Ivanovna and Aleksander Jagiellonczyk. In: Frictions and Failures. Cultural Encounters in Crisis. Ed. Almut Bues. Wiesbaden 2017 (= Deutsches Historisches Institut Warschau. Quellen und Studien 34), pp. 181-200.

11 For an overview of Pskovian paintings, seе Литшиц, Лев И.: Очерки истории живописи древнего Пскова. Середина ХIII - начало XV v. Становление местной художественной традииии. Moskva 2004.

12 Лифшиц, Лев И.: Программа росписи Снетогосрскохо монастыря. In: Вопросы русского и советского искусства. Том. 3: Материалы научных конференций. 1972-1973 гг. Moskva 1974, pp. 21-51; idem: О стиле росписи Снетогорского монастыря. In: Древнерусское искусство. Монументальная живопись XI-XVII vv. Moskva 1980, pp. 93-114; ГолуБевА, Ирина Б. - САРАБянов, Владимир Д. D.: Собор рожде ства Богородичъ Снетогосрского монастрыря. Moskva 2002, pp. 24-62.

13 БЕлецкий, Василий Д.: Живопись в храмах XIV в. из раскопок в Довмонтовом городе Пскова. In: Древнерусское искусство. Монументальная живопись XI-XVII vv. Moskva 1980, pp. 210-242; ПоповА, Елена А.: Монументальная живопись Древнего Пскова последней четверти XIV - начала XV века: проблема иконографии и стиля. In: Классика в искусстве сквозь века. Сборник научных статей. Edd. Светлана В. Мальцева - Екатерина Ю. Станюкович-Денисова - Екатерина А. Скворцова. Труды исторического факультета С.-Петербургского государственного университета. Санкт Петербург 2015 , рр. 55-69.

14 Стенное письмо строения великих князей Тверских. Фрески черкви Рождества Богородицы в Городне. Каталог. Ed. Ирина А. Шалина. Moskva 2015; Беляев, Леонид А. - САфАровА, Ирина А.- Хохлов, 
warm earth colours, and finishing with thick white strokes and dots - key features of the Pskov School - were not only characteristic of Pskov, but also in much larger northern areas, including those of the Grand Duchy of Lithuania.

It is unknown when the Byzantine paintings crossed religious borders and became established in the castles of the then pagan grand dukes of Lithuania. From the whole of the grand duchy, the paintings from Kreva and Medininkai are the earliest surviving examples of mural decoration in castles. One can only speculate whether such paintings adorned the interiors of wooden buildings, as there are no traces or records of them. Therefore, it is unknown how pagan viewers perceived Byzantine murals, or whether they related these paintings to Christianity. Indirect allusions to their visual reception appear only in the later fifteenth century in the Annals by Jan Długosz (1415-1480). The Polish chronicler relates how the Grand Duchess Uliana of Tver' (c. 1325-1391) had a "bad" influence on her son, Jogaila, the future King Wladislas II of Poland. In Jogaila's obituary, Długosz summarizes the king's reign and character. Among other features, the king is said to have observed certain superstitions, which he took from his mother, a woman of "Greek rite." ${ }^{15}$ Interestingly, examples of a detrimental maternal impact inform Długosz's account of Jogaila's pious deeds, including the list of Greek wall paintings that the king commissioned for the churches and chapels in Poland. ${ }^{16}$ Was the king's preference for Greek paintings part of the superstitions he inherited from his Orthodox mother? Perhaps the Grand Duchess Uliana was the catalyst for the transfer of skills and preferences for painted interiors to her marital realm. In the sixteenth century, the chronicler Maciej Stryjkowski (1547 - c. 1596) even wrote that Uliana had commissioned portraits of herself and her [pagan!] husband Grand Duke Algirdas (reign 1345-1377) that were painted in the Orthodox church in the Upper Castle of Vitebsk. ${ }^{17}$ It is surprising to read about the portrait of a pagan duke who martyred Orthodox converts, ${ }^{18}$ being painted in an Orthodox church; however, this fact did not surprise Stryjkowski, nor I could find any traces of religious uneasiness of the Orthodox masters working for pagan lords.

Аелксандр Н.: Спасо-Преображенский собор в Тверском кремле: итоги раскопок 2012-2014. Российская археология 2, 2018, pp. 148-161; I am grateful to Dr. Sergey Polekhov for this reference.

15 Joannis Dlugossii Annales seu cronicae incliti Regni Poloniae. Liber 11-12 (1431-1444). Ed. Gregorius Wyrozumski et al. Varsaviae 2001, p. 125: Certarum supersticionum, quas eum quidam asserunt ex bona causa continuasse, et quas illum mater sua ritus Grecorum femina asserebatur instruxisse, sectator, and ibidem, p. 127: Singulis diebus, antequam in publicum exiret, ter se in gyrum volvebat, terque stipulam a se confractam in terram proiiciebat: a matre Grecorum ritus dum adulescenciam ageret ea agere edoctus.

16 Ibidem, pp. 125-127. For an in-depth discussion and source evidence on contemporaneous perceptions of King Wladislas II and his reign, see Biedrowska-Ochmańska, Krystyna - Ochmański, Jerzy: Wtadystaw Jagietto w opiniach swoich wspótczesnych: próba charakterystyki jego osobowości. Poznań 1987.

17 ... pirwßa Xieżna Witebska Uliana [...] y ktorey ia obraz tymi oczyma widziat po staroswiecku roku 1573 malowany wespotek z Olgerde [m] mężem na zamku Wicebskim wyßnym w Cerkiew ce staroswieckiey drzewianey na podmurzu. Ktory zamek y wieże ta sama Xiężna zmurowata w niebytnośći Olgerdowey, see in STrYJKowski, Maciej: Kronika Polska Litewska, Zmodzka, y wszystkiey Rusi Kijowskiey, Moskiewskiey, Siewierskiey, Wotynskiey, Podolskiey, Podgorskiey, Podlaskiey, etc. Królewiec 1582, pp. 461-462.

18 On the martyrdom of Algirdas' courtiers Anthony, John, and Eustachius, see Baronas, Darius: Trys Vilniaus kankiniai. Gyvenimas ir istorija = Tres martyres Vilnenses. Vita et historia. Vilnius 2000. 
Apparently, Byzantine murals became part of the grand ducal court and functioned as visual uniformity in interior decoration. This uniformity meant that those who commissioned the paintings did not see the paintings as representing Christianity or its Orthodox branch, but accepted the murals as the vernacular style and enjoyed these paintings for several generations.

\section{Observing the religious divide}

\subsection{Reservations of the Catholic Clergy}

The extent to how deeply the preference for Byzantine murals was rooted in the Lithuanian grand ducal family might be estimated by their "exportation" to Poland after Grand Duke Jogaila was elected and crowned King Wladislas II in 1386. Art history has characterized the king as being the patron of Byzantine wall paintings; yet again this is based on later opinions (principally that of Jan Długosz ${ }^{19}$ ). Scholars claim that royal commissions were the exception rather than playing a dominant role in the arts. ${ }^{20}$ Noteworthy is not the number of Byzantine murals ordered by the king, but the consistency. Throughout his long reign, the interiors of seven Catholic churches and chapels are known to have been decorated with Greek paintings: the Benedictine Church of the Holy Cross in Lysa Góra (1393-1394); the Archcathedral of the Assumption of the Virgin Mary and St Adalbert in Gniezno (1390s); the Church of the Nativity of the Virgin Mary in Wiślica (c. 1400); the Church of the Nativity of the Virgin Mary in Sandomierz (between 1403 and $1416^{21}$ ); the Chapel of the Holy Trinity in Lublin Castle (1418); the Chapels of the Nativity of the Virgin Mary $(1420)^{22}$ and of the Holy Trinity, both in Krakow Cathedral (1431-1432). ${ }^{23}$ The sole known secular commission was the decoration of

19 Joannis Dlugossii Annales. Liber 11-12, p. 126.

20 Jurkowlaniec, Grażyna: The Artistic Patronage of Ladislas Jagiello. Beyond the Opposition between Byzantium and the Renaissance. In: Byzantium and Renaissances. Dialogue of Cultures, Heritage of Antiquity - Tradition and Modernity. Edd. Michał Janocha - Aleksandra Sulikowska - Irena Tatarova - Zuzana Flisowska - Karolina Mroziewicz - Nina Smólska - Krzysztof Smólski. Warszawa 2012, pp. 271-281.

21 The dating of the paintings is based on the depiction of the arms of Queen Anna of Cilli (r. 1402-1416), the second wife of King Wladislas II, represented in a heraldic frieze on the northern wall of the apse, see SMORĄG-RóżYCKA, Małgorzata: Byzantyńskie freski w sandomierskiej katedrze. Królewski dar na chwate Boża czy odblask idei unii horodelskiej? Prace Historyczne 141/2, 2014, pp. 235-255.

22 For a recent account on the paintings see the manuscript in The Archives of the Cracow Cathedral Chapter (= Archiwum i Biblioteka Krakowskiej Kapituły Katedralnej - AKKK), Kons. 209: ZALewski, Władysław - Komornicka, Magdalena - Manon, Agata - Pierzchalska, Katarzyna: Dokumentacja konserwatorska dla malowidet ściennych w kaplicy Mariackiej przy katedrze na Wawelu w Krakowie. Kraków 2007.

23 For a summary of the available source evidence and scholarly interpretations of Byzantine wall paintings in Poland see Kruk, Mirosław Piotr: Malowidta Graeco opere fundacji Jagiellonów jako postulat unii państwowej i kościelnej oraz jedności Kościota. In: Między teologią a duszpasterstwem powszechnym na ziemiach Korony doby przedtrydenckiej. Dziedzictwo średniowiecza i wyzwania XV-XVI wieku. Ed. Wacław Walecki. Kultura Pierwszej Rzeczypospolitej w dialogu z Europą. Hermeneutyka wartości 5. Warszawa 2017, pp. 152-155. 
a royal bedchamber in Wawel Castle (1394). ${ }^{24}$ Our knowledge of these murals executed in or ascribed to the Greek style comes either from later records or circumstantial evidence; no record testifies to the king's intentions or conveys opinions from the time.

King Wladislas' II preference for Byzantine wall paintings obviously had Lithuanian roots; however, scholarly interpretations of their transfer to Poland range from bringing a familiar visual environment to the new realm, to differentiating the king's distinct origins from the previous ruler's, to being a visual statement of confessional unity. While discussion on these murals cannot be exhaustive, their internal evidence suggests that the royal penchant for displaying religious differences on church walls was accepted with reservation on the part of the Catholic clergy.

The vast majority of Byzantine murals surviving from Wladislas' II reign bear Old Church Slavonic captions in Cyrillic. In addition, those in Wiślica have trilingual inscriptions in Cyrillic, Greek, and Latin; in Sandomierz the captions are bilingual - Cyrillic and Latin - while only Latin captions have been found in the Chapel of the Nativity of the Virgin in Krakow. The different languages of the inscriptions attest to the different creators who were responsible for them. Clearly, Cyrillic and Greek captions might be attributed to Orthodox masters and the Latin ones must have been written by Catholics. Anna Różycka-Bryzek has argued that the Latin inscriptions testify to interference by the local clergy in the painters' work and alterations to the visual content of the murals. ${ }^{25}$ This reasoning also applies to the Greek and Latin inscriptions on Byzantine murals in Catholic churches in the bi-confessional Balkans. There bilingual inscriptions are to be found after the conclusion of the Union of Florence (1438) and are regarded as Catholic legitimation of the union on a visual level. ${ }^{26}$

Working in Catholic churches and chapels, the masters could not and did not follow the traditional iconographic programme of the Orthodox church. Deviations from the usual layout of compositions were necessary not only because of alterations to the architecture, but also, as Agnieszka Gronek has observed, because of the partial character of these Byzantine decorations. ${ }^{27}$ None of the extant Byzantine murals in Poland occupies the entire interior of the church: they are either located in presbyteries, as in Sandomi-

24 The paintings are known from reports in royal accounting books: Item pro II talentis cynobrii ad depingendum dormitorium dni Regis in castro Cracoviensis I sexag. / Item pro vasis scilicet ollis etc. in quibus colores varii per pictores Ruthenicos seruantur I sc. XIV den. (12. 7. 1394); Item feria IV post diem Assumpcionis pro I1/2 talento cinobri ad depignendum dormitorium dni Regis in castro Cracoviensi III fert. (19. 8. 1394); item pro II equis datis ad mandatum dni Regis Ruthenis pictoribus dormitorii in castro Cracoviensi V marc. (20. 11. 1394), Rachunki dworu króla Wtadystawa Jagietty i królowej Jadwigi z lat 1388 do 1420. Ed. Franciszek Piekosiński. Kraków 1896, p. 201, 202, 211.

25 Różycka-Bryzek, Anna: Bizantyńsko-ruskie malowidta w Polsce wczesnojagiellońskiej. Problem przystosowań na gruncie kultury tacińskiej. In: Polska - Ukraina. 1000 lat sąsiedztwa. Tom 2: Studia z dziejów chrześcijaństwa na pograniczu kulturowym i etnicznym. Ed. Stanisław Stępień. Przemyśl 1994, pp. 307-326.

26 Đurić, Vojislav J.: U senci Firentinske Unije - Crkva Sv. Gospođe u Mržepu - Boka kotorska. Zbornik radova Vizantološkog instituta 35, 1996, pp. 9-56; idem, Jezici i pismena na srednjovekovnim fresko - natpisima u Boki Kotorskoj in Crkva Svetog Luke kroz vjekove. In: Naučni skup povodom 800-godišnjice crkve Svetog Luke u Kotoru (Kotor 20-22. oktobar 1995). Ed. Vojislav Korać. Kotor 1997, pp. 261-262.

27 Gronek, Agnieszka: Opuszczone dziedzictwo. O malowidtach w cerkwi św. Onufrego w Posadzie Rybotyckiej. Kraków 2015, p. 362. 
erz and Wiślica, or chapels, of which only the one in Lublin Castle might be considered an independent structure with limited access from outside of the castle. Being part of Lublin Castle, the chapel may have escaped the debates concerning its decoration; thus becoming the sole example of monolingual captions in Cyrillic. The smaller space and scale of chapels made their architecture, interior arrangement, and, to a certain extent, their liturgical services, much more dependent on their founders. However, interference in the larger spaces of churches required negotiations with the clergy. It would have been difficult for the canons to refuse a royal donation, but it was within clerical authority to designate where the art work would be located. Perhaps it was not by accident that the presbyteries rather than naves of the two collegiate churches were chosen to be painted with Byzantine murals. By doing so, the visually and confessionally different images were spatially distanced from the congregation gathered in the nave. Having been imposed by the king on the church, these paintings remained behind the rod-screen and the high altar as visually present though liturgically passive images. In accordance with Różycka-Bryzek's opinion, the Latin inscriptions probably indicated the reserved clerical acceptance of these confessionally different murals. The heterodoxy of Byzantine murals was bridged by supplementing images with visually and religiously vernacular Latin inscriptions. Written on the walls of the presbytery, these inscriptions were seen by the congregation and could be read by clerics at the high altar. With their location reserved for the literate and dignitaries, these painted presbyteries may have provided a model of the reality of confessional unity - reserved for the learned and authorized by Latin concepts and inscriptions. Of course, looking at the Byzantine paintings on the walls of a Catholic church and seeing there the promise of the Church Union yet to come is an established scholarly view, ${ }^{28}$ related not so much to the Latin inscriptions, but rather to the recognizable difference of the Byzantine images and the uniformity of the Gothic architecture. In the Cathedral of Sandomierz, the images of five holy bishops (Fig. 9), two dressed in "Greek" vestments and labelled bilingually as St Nicholas of Myra and St Basil the Great, and three wearing "Latin" clothing, whose names are unknown due to the missing inscriptions, clearly represent distinct Christian rites in a single picture. Most likely, the five bishops belonged to a shared Christian past before the schism. The figures of the bishops might represent some bi-confessional concerns - perhaps they were viewed as representing the two rites of the United Church, outnumbered by the followers of Catholicism. The assumption that the paintings show confessional unity under the Catholic supremacy established in Florence in 1438 is correct in retrospect. However, interpreting these paintings as representing the integration of the two Christian confessions would not only imply a highly sophisticated visual thinking, but it would also mean that visual articulation surpassed that of language. Instead of starting a competition between the ways that ideas were expressed in the Middle Ages, I view these paintings as an attempt at adapting the Eastern and Western visual repertoire. ${ }^{29}$

28 Kruk, M. P.: Malowidta, pp. 196-198.

29 This integration was not limited to confessional issues. The heraldic frieze which was opened in the Cathedral of Sandomierz in 2008 shows painters copying heraldic signs. On the frieze see GiergIEL, Tomisław Pтак, Jan: The Heraldic Frieze Discovered in Sandomierz Cathedral. In: The Polish Heraldry Society Yearbook 
The painted presbyteries in Wiślica and Sandomierz can be interpreted as visual testimonies to the negotiations on the visual level. Perhaps they represented the reality of how the Catholic king could bridge the schism by accepting Orthodox people as marginalized and culturally colonized. If such a projection onto the medieval past is correct, these confessionally different paintings visualized Church unity under Catholic guidance and royal benevolence.

\subsection{Orthodox intentions}

While the paintings and records from Poland testify to the partial character and altered content of the Byzantine murals, the decoration in the church and the Island Castle of Trakai in Lithuania has been made from the Orthodox perspective. The parish Church of the Visitation of the Virgin Mary and St John the Evangelist was founded by Grand Duke Vytautas in $1409 . .^{30}$ The construction of the church must have taken around a decade, as the first known priest named Michael was recorded in 1419. ${ }^{31}$ Yet again, no historical record mentions the paintings. A report from 1555 states that the portrait of Vytautas in the church corresponded to the description of the grand duke's appearance $;^{32}$ however, there is no mention of the style or the location of the portrait within the interior. References to the murals appear in the first half of the seventeenth century and refer to these paintings as being ancient ${ }^{33}$ or Greek. ${ }^{34}$

In contrast to the Polish examples discussed above, the murals in Trakai show no evidence of Catholic control. In addition, an analysis of the style, composition, iconography,

= Rocznik Polskiego Towarzystwa Heraldycznego NS 10/21. Ed. Sławomir Górzynski. Warszawa 2011, pp. 3-38; Sмorág-RóżycKa, Małgorzata: Bizantyńskie malowidta w prezbiterium katedry pw. Wniebowzięcia Najświętszej Marii Panny w Sandomierzu - odkrycia niespodziewane i donioste. Modus. Prace z Historii Sztuki 12/13, 2013, pp. 53-72; eadem: Bizantyńskie freski; eadem: Anna Cylejska - zapomniana patronka bizantyńskich malowidet w prezbiterium katedry pw. Wniebowzięcia Najświętszej Marii Panny w Sandomierzu. In: Patronat artystyczny Jagiellonów. Edd. Marek Walczak - Piotr Węcowski. Studia Jagiellonica 1. Kraków 2015, pp. 289-304.

30 Vitoldiana. Codex Privilegiorum Vitoldi Magni Ducis Lithuaniae, 1386-1430. Ed. Jerzy Ochmański. Warszawa 1986, no. 21, pp. 27-28.

31 AlišAuskas, Vytautas - JaszczoŁt, Tomasz - JovaIšA, Liudas - PAKnys, Mindaugas: Lietuvos kataliku dvasininkai XIV-XVI a. Bažnyčios istorijos studijos 2. Vilnius 2009, no. 1605, pp. 286-287.

32 Martini Cromeri De Origine et Rebus Gestis Polonorvm Libri XXX. In: Polonicae Historiæ Corpvs: Hoc est, Polonicarvm Rervm Latini Recentiores \& Ueteres Scriptores, quotquot Extant, Uno Volumine Compræhensi Omnes, \& in Aliquot Distributi Tomos; Ex Bibliotheca Ioan. Pistorii Nidani. Vol. 2. Basilea 1582, p. 687: [Vytautas] quadem apud Trocos in templo depictus vidimus.

33 [WołŁowicz, Eustachius]: Relatio anni 1625. In: Relationes status diocesium in Magno Ducatu Lithuanie. Vol. 1. Ed. Paul Rabikauskas. Roma 1971, p. 59: [...] vero in praepositura Trocensis ipsa vetuste decora.

34 Kościol farski trocki, cudami Przenawetszey Bogarodzice Panny Maryey obiaśniony a prez xiędza Symona Mankiewicza biskupstwa Zmudzkiego dyocesiana nowo na świat wystawiony. Wilno 1645, p. A3r: ... i sam Kościol byt wßytek z staroswiecka po Grecku malowany; Miscellanea rervm, ad statum ecclesiasticum in Magno Litvaniae Dvcatv pertinentia. Collecta ab Alberto Wiivk Koiatowicz Societ Jesu S. Theol. Doct. Almae Universitatis Vilnensis procancellario et ordinario $S$. Theol. Professore vulgata superiorum permissu. Vilnae 1650, p. 26: prout $\mathcal{E}^{2}$ totius templi parietes ante erant ornati picturis Graeco habitu. 
and epigraphy of the paintings allowed me to attribute them to the Morava School of late-medieval Serbia. ${ }^{35}$ Before going into the details of the iconography, it is worth mentioning that Gregory Tsamblak ${ }^{36}$ (c. 1364-1419/20), the Bulgarian-born Metropolitan of Kyiv, is considered to be the intermediary who acquired the commissions in Lithuania for the Serbian masters. After his native city of Veliko Tyrnovo fell to the Ottomans in 1393, Tsamblak served as an envoy of the Patriarch of Constantinople in Valachia and later became the abbot of Dečani monastery in Serbia. In 1406, he left Dečani for Moscow, intending to meet his fellow Tyrnovian Metropolitan Cyprian (reign 1376/90-1406). On his way northwards Tsamblak learned about Cyprian's death (16.9.1406) and lamented this loss "by the Nemunas River in Lithuania." ${ }^{37}$ In 1414, Grand Duke Vytautas promoted him to the office of Metropolitan of Kyiv as a Lithuanian alternative to Metropolitan Photius (reigned 1407-1431), who resided in Moscow. Despite the disapproval of the Patriarch of Constantinople, the Orthodox bishops of the grand duchy elected Tsamblak as metropolitan in 1415. It is no secret that Vytautas engineered this election. ${ }^{38}$ In 1418, the metropolitan travelled to the Council of Constance (1414-1418), where he represented the Orthodox population of Poland and Lithuania and participated in talks on the union of the Church. ${ }^{39}$ While Tsamblak is best known for his religious writings and political activities, a study of the Trakai paintings draws attention to his abbacy in Dečani, which he left in 1406 for the trip northwards. Written sources do not mention Tsamblak's companions, but it is certain that he did not travel alone. Perhaps the former abbot was accompanied or later joined by some painters who received commissions in Trakai.

Fragments of paintings scattered around the nave show that the entire interior of the parish church was painted with Byzantine murals. Of all the remnants, the composition of the Last Judgement can be reconstructed from the surviving figures of the Patriarch Jacob, the tree of Paradise, and the Procession of the Elect (Figs. 10-13). As the study of the iconography is principally concerned with the subject matter rather than the skill behind the pictures, I examined the ideologies and narratives behind the visualization of the Last Judgement in Trakai.

35 MickūNAité, Giedrè: Traku bizantinè tapyba ir antroji pietu slavu itakos banga. In: Dailès kūrinys - istorijos šaltinis. Ed. Skirmantė Smilingytė-Žeimienè. Vilnius 2016, pp. 8-41.

36 Thomson, Francis J.: Gregory Tsamblak. The Man and the Myths. Slavica Gandensia 25/2, 1998, pp. 1-144.

37 ДончевА-ПанаиотовА, Невиана: Слвото на Григории Цамблак за митрополит Киприан. Veliko Tyrnovo 1995, p. 96: Идуши ми к вам, яко же и доспева рек - и тамо река убо Геон беаше, идеже пленении они себеж и оръганы молчанию осудиша - река ж Немон бяше, притикаюшия Литьвы, на неи ж горькому нас стретьиию возвещению.

38 MickūNAité, Giedrè: Making a Great Ruler. Grand Duke Vytautas of Lithuania. Budapest - New York 2006 , pp. $46-47$.

39 Thomson, F. J.: Gregory Tsamblak, pp. 54-103. The issue of the union of the Church was on the agenda of the Council of Constance; however, this causa fidei was left unsettled as after the election of Pope Martin V (1417-1431), delegates from the Catholic countries started leaving the Council. Tsamblak's position towards the union is unknown as there are two contradictory speeches attributed to the metropolitan. The speech noted in Latin in the diary of Cardinal Guillaume Fillastre (1348-1428) agrees with the union; another one known from copies in Old Church Slavonic is against the union, sее БЕгунов, Юрий К.: Твориеское наследие Григория Цамблака. Veliko Tyrnovo 2005, pp. 180-184 and pp. 438-441. 
The complex iconography of the end of time has been assembled from Biblical narratives (Dan 7; Mt 25:31-46; Rev) and holy visions, of which those attributed to St Ephrem the Syrian (c. 306-373), but recorded in Greek a long time after Ephrem's death, are viewed as having the greatest impact on the development of the imagery. ${ }^{40}$ In Christian tradition, especially in its Orthodox branch, the Last Judgement is considered instrumental in spreading and sustaining the faith. The image of the End of Times horrifies the viewer and determines to struggle for the salvation of the soul. Byzantines regarded images of the Last Judgment as a missionary tool, as a means to indoctrinate neophytes by sustaining the fear of being driven to hell in the afterlife. At the turn of the fourteenth century, the number of representations of the Last Judgement decreases in Byzantine art, except in Serbia. Threatened by the Ottoman advance, Serbian rulers and local potentates displayed their authority with an eschatological mission for the salvation of Christian souls, and images of the Last Judgement became almost mandatory in church decoration..$^{41}$ Gregory Tsamblak also contributed to this tradition. In the Life of St Stefan III Uroš (1276/82-1331), the founder of Dečani monastery, Tsamblak wrote:

\footnotetext{
"On the dreadful Day of Judgement, when you [St Stefan] will shine even more brightly than the sun, you will gather us around who have called themselves the flock of your enclosure and, having shown (us) to God the judge, you will utter that blessed cry: 'Here am I and the children whom God gave me."”42
}

Copies of St Stefan's Life that circulated in the north imply that the Life's author shared his views and knowledge with an actual or potential northern flock. ${ }^{43}$ Gregory Tsamblak, together with Constantine the Philosopher (c. 1380 - after 1431), two distinguished representatives from the Veliko Tyrnovo School of Rhetoric, are regarded as those whose ideas nourished the iconography of the Morava School. ${ }^{44}$ Perhaps Tsamblak played a similar role after moving to Lithuania. Even if Tsamblak can be considered as the Orthodox influence behind the iconography of the Trakai church, painters were required to carry out this programme.

Assumptions about the painters can only be derived from their works; therefore, it is worth noting that not only the church of Trakai, but also the nearby Island Castle was

40 Ortiz da Urbina: La paradis eschatologique d'apres Saint Ephrem. Orientalia Christiana Periodica 21/34, 1955, pp. 467-472; HiмkA, John-Paul: Last Judgment Iconography in the Carpathians. Toronto 2009, pp. $208-212$.

41 Давидов-Темерински: Александра: Империјални смисао дечанског сликарства. Уводна разматрана. . Vol. 2. Ed. Miša Rakocija. Niš 2004, pp. 241-252; eadem: Слике Страшног суда са позитивним исходом:Тимотесубани, Ахтала и Дечани. In: Niš i Vizantija. Vol. 8. Ed. Miša Rakocija. Niš 2010, pp. 317-320.

42 Житиена Стефан Деиански от Григорий Цамблак. Edd. Ангел Давидов - Георги Данчев - Невяна Ангелова Дончева-Панайотова. Sofia 1983, pp. 136-137. The English translation quoted after Thomson, F. J.: Gregory Tsamblak, p. 43.

43 For the Vilnius copy of the Life of St Stefan, see “Житие на крал Стефан Дечански” in: КЕнанов, Димитър: Озареният Григорий Цамблак. По материали от Вилнюските рвкописни и старопечатни сбирки. Veliko Tyrnovo 2000, pp. 177-186.

ĐJurić, Vojislav J.: Moravsko slikarstvo = La Peinture de L'école de la Morava. Beograd 1968, p. 31. 
once decorated with Byzantine murals. Built in the first decade of the fifteenth century, ${ }^{45}$ the castle was a favourite residence of Grand Duke Vytautas ${ }^{46}$ and it maintained its residential function throughout the fifteenth century. As with most of the wall paintings, this decoration was described, copied, and photographed in the nineteenth and first half of the twentieth century. While the paintings have been largely lost, the identical structures of the base plaster in the church and the castle suggest the decoration was made by the same masters and so they can be interpreted as complementary pieces.

Of all the visual documentation of the paintings in the Island Castle, the sketches by Wincenty Smokowski (1797-1876) of the murals in 1822, which were integrated into a lithograph published in 1841 (Fig. 14), are the most informative pieces. The photographs (Figs. 15, 16) add to our understanding of these paintings, while Jerzy Hoppen's (1891-1969) 1:1 copies from 1932 (Fig. 17) show the scale and colours. There is a man in Smokowski's lithograph dressed in Byzantine imperial costume and wearing stemma-like headgear, who repeatedly appears in the scenes of the murals. It is worth noting that this anonymous ruler, in contrast to other Byzantine images of emperors and Orthodox potentates, is depicted without a halo. It is highly tempting to identify the ruler featured in the palace of Trakai as Vytautas, but unfortunately this cannot be supported by inscriptions or contemporaneous portraits of the grand duke. However, the parallel with the similarly untitled portraits of King Wladislas II Jogaila in the Chapel of the Holy Trinity (1418) in Lublin Castle (Figs. 18, 19) might shed light on the representation of a Catholic lord painted by an Orthodox master. The two portraits show Wladislas II without a halo and thus deprive the king of the sanctity of God's chosen. ${ }^{47}$ In Lublin, painters indicated the confessional and cultural differences of their patron by omitting the halo around the king's head and dressing him in Western garb. In the palace of Trakai, the principle of confessional difference was observed in a more nuanced way: judging from copies, the absent nimbus in the image of the ruler in Trakai is the only divergence from the portrayals of Orthodox potentates in Byzantine art. To sum up, painters working in Lublin and in Trakai employed iconographic absence to observe and show the confessional difference of their patrons. Apparently, such a principle was sufficient for the masters and

45 On the history and urban development of Trakai, see BALiulis, Algirdas - Mikulionis, Stanislovas - MišKINIS, Algimantas: Traku miestas ir pilys. Istorija ir architektūra. Vilnius 1991.

46 The sources do not mention the construction of the castle. The year of completion is established on the basis of the grand duke's itinerary, which shows frequent residencies in Trakai from 1409, see Purc, Jerzy: Itinerarium Witolda wielkiego księcia Litwy, 17 lutego 1370 roku - 27 października 1430 roku. Zeszyty Naukowe Uniwersytetu im. Adama Mickiewicza w Poznaniu. Historia 11, 1971, pp. 89-109.

47 For the development of representations of the emperor in art, see L'Orange, H. P.: Sol Invictus Imperator. Ein Beitrag zur Apotheose. Symbolae Osloenses 14/1, 1935, pp. 86-114; Grabar, André: L'empereur dans l'art byzantin; recherches sur l'art officiel de l'empire d'Orient. Paris 1936. The available portraiture shows that until 13 th century haloes were reserved for emperors alone; however, later centuries testify to the expansion of nimbi, which started surrounding the heads of Orthodox potentates of Bulgaria and Serbia, and by 15th century became an almost mandatory attribute of lay church founders and donors, for a thorough overview of later Byzantine portraiture, see Velmans, Tania: Le portrait dans l'art des Paléologues. In: Art et Société a Byzance sous les Paléologues. Actes du Colloque Organisé par l'Association Internationale des Études Byzantines a Venise en septembre 1968. Venezia 1971, pp. 93-148. 
did not bother Catholic viewers, for whom a halo meant sanctity rather than kingship by the grace of God.

Based on the available evidence, the painters employed in Trakai used Byzantine visual language for the needs of Lithuanian neophytes without abandoning the principles of the Orthodox faith. The surviving paintings in the parish church and the copies of those from the palace do not suggest any Catholic interference in the content of the murals. Of course, the decoration was adapted to the architecture, however, these adjustments were confessional only to the extent that the architecture was confessional: for example, the Last Judgement was painted within the nave as the gothic hall-church had no narthex. Viewed from the perspective of the relationship between the patron and the masters, the latter might be seen as the active part, carrying out the commission from the passive patron. The opposite relationship might be inferred from an analysis of the Crucifixion in Vilnius Cathedral.

\subsection{Iconography under supervision}

The Crucifixion with the Virgin Mary and St John the Evangelist (Fig. 20) in the funerary crypt of the Vilnius Cathedral has been dated to approximately $1400 .{ }^{48}$ The composition shows Jesus crucified, a halo inscribed with a cross surrounding his head, which is resting on his right shoulder. The figure of the Virgin Mary is depicted wearing a dark grey-blue tunic under a long reddish-brown maphorion. St John is clad in a light-blue tunic. Although all the features listed above have been used in the art of both Christian confessions, the rigid drawing, the even colouring, as well as the colours of the Virgin's garments indicate the Byzantine tradition.

By the Late Middle Ages, the major iconographic difference in representing the Crucifixion in the East and West was shown by the number of nails piercing Christ's feet and the number of horizontal beams of the cross. As a rule, the Orthodox tradition featured Christ with four nails: each palm and foot was nailed separately to a cross with two horizontal bars, ${ }^{49}$ the top for the hands and the bottom for the feet of the victim. By contrast, Catholic iconography followed the so-called three-nail scheme of crucifixion, showing the Lord's feet nailed with one nail directly to the vertical beam of a cross which had one horizontal bar. It must be mentioned that Catholic imagery was neither rigid or definitive, and over time the disputes concerning three versus four nails on the crucifixion favoured the number three for being more symbolic of Christian thought, rather than adhering to

48 The Crucifixion scene $(144,5 \times 137,5 \mathrm{~cm})$ is painted al secco on the northern wall of the crypt under the southern aisle of today's cathedral. The mural's restoration documents are kept in the archives of the Cultural Heritage Centre of the Ministry of Culture of the Republic of Lithuania: Kultūros paveldo centro archyvas, F. 40, Ap. 1, B. 453: 'Kultūros paminklo restauravimo pasas: 85-1-274/DS12 (334). Paminklo pav.: Nukryžiuotasis su Marija ir šv. Jonu evangelistu. Buv. Vilnius Katedros pietu navos kriptos sienu tapyba. 14 a. pabaiga (?). Aut. Nežinomas. Rest. J. Pilipavičius, P. Kuodis'.

49 This description of the cross of the Crucifixion does not consider the table with the inscription of Jesus's sentence abbreviated as INRI being a horizontal bar; however, some medieval sources used to count the table as the top bar of the cross. 
the four-nail image, which was perhaps closer to historical truth. ${ }^{50}$ In the Orthodox tradition, the bottom bar of the cross stands for the sacrifice of truth for a symbolic message: the footrest under Christ's feet refers to his majesty and heavenly lordship. ${ }^{51}$

Looking at the Vilnius Crucifixion through a confessional lens, one sees the composition as having been painted in a Byzantine style but with Western iconography. The two Christian traditions were combined in single mural, albeit in different proportions. Christ nailed with three nails to a two-bar cross declares undoubted adherence to Western principles. However, all the other features betray the Orthodox schooling of the master, who not only painted the crypt, but also inscribed his painting. I refer to traces of the characters " $\omega$ " and "и" seen on the right and left rays of the Lord's cruciform nimbus (Fig. 21, the sides are indicated in reference to Christ). In Byzantine art, the cross in Christ's nimbus was inscribed with the characters "O $\Omega \mathrm{N}$ " on the rays at the top, right, and left. ${ }^{52}$ The abbreviation, meaning "the One who is" and alluding to the Lord's words to Moses "I am who I am" (Ex 3:14), indicates the incarnation of God in man. In the Late Middle Ages, these characters came to be written lowercase as "owv." In medieval Russian Orthodox painting, the Greek character "N/v" used to be written as "N", which by the end of the fifteenth century was replaced with Cyrillic "н". The characters in the cruciform nimbus attest to the Orthodox background of the painter, while the reversed character "N" implies that he was barely literate. Apparently, the anonymous master was commissioned to decorate the funerary crypt in the cathedral. The unknown patron who ordered the mural insisted on following the principles of Catholic iconography. This task was not an easy one as shown by the inconsistency in Christ's arms pulled down by the weight of his body and the very straight legs stretched down the pole of the cross. Ignoring the gravity of the body attests to the master's endeavours to observe the threenail requirement instead of following the habitual four-nail scheme.

If there is credibility to this hypothesis of the creation of the Vilnius Crucifixion, perhaps it was a person (maybe a churchman) who instructed the painter on matters of Catholic iconography. Therefore, the anonymous patron attempted to have a "proper" Crucifixion in the funerary crypt, whose decoration was not aimed at a viewer, but functioned as a sign of Christian death and the hope of bodily resurrection. The Crucifixion

50 E.g., the prominent theologian William Durandus (c. 1271-1330) favours the three-bar (he calls it four-bar by also counting the table of the sentence) cross, but also includes the explication of the symbolism of the two-bar, see Dvrantus, Guillemus: Rationale Divinorvm officiorvm V-VI. Edd. Anselme Davril - Timothy M. Thibodeau. Corpus Christianorum Continuatio Mediaevalis 140A. Turnhout 1998, p. 380. The issue of a truthful representation of Jesus crucified also bothered Krakow's intellectuals in the 16th century: nostri pictores [...] errant et in imagine crucifixi, non enim tribus clavis, sed equidem Gr<a>ecorum tabula equator affixum corpus Domini nostri Iesu Christi aperte testantur, see Rydzyński, Piotr: Historia pulchra. In: Najstarsze historie o częstochowskim obrazie Panny Maryi. XV i XVI wiek. Edd. Henryk Kowalewicz - Monika Kowalewiczowa - Zofia Rozanow. Warszawa 1983, p. 169. For a concise but in-depth study concerning the number of nails, see CAMEs, Gérard: Recherches sur les origines du Crucifix a trois clous. Cahiers Archeologiques 16, 1966, pp. 185-202.

51 See Grube, Ernst: Majestas und Crucifix. Zum Motiv des Suppedaneums. Zeitschrift für Kunstgeschichte 20, 1957, pp. 268-287.

52 It must be noted that from the 17th century the location of the characters "o" and " $\omega$ " changed places within the cruciform nimbus. 
thus reveals Catholic supervision concerned with iconography rather than style, which was arguably not only the vernacular of the painter, but also of his patron.

\section{A conscious style}

The very last piece of Byzantine mural decoration in a Catholic church commissioned in Poland was for the Chapel of the Holy Cross of the Krakow Cathedral in 1470. The chapel, which was erected on the southern side of the cathedral's main western entrance, was built as the resting place of King Casimir IV Jagiellon (reign 1447-1492), Queen Elisabeth of Austria (reign 1454-1505), and their daughters who died in minority. Its location and architecture complemented the Chapel of the Holy Trinity, the final resting place of the king's mother, Queen Sophia (reign 1427-1461). The two chapels not only flank the cathedral's main portal, complementing each other with their architecturally similar exteriors, but they initially also shared a Byzantine style of painted interiors. While the decoration of the Holy Trinity Chapel, which was carried out between 1431 and 1433, concludes the series of King Wladislas' II commissions, the murals in the Chapel of the Holy Cross can be viewed as a visual statement of the ruling house made by the king's son and successor. This was the sole order for Byzantine murals which Casimir IV made, and was separated by four decades from the commissions by his father. This work is an exception within the patronage of the royal couple as well as within the artistic practices prevalent in their realm. Singled out by their (post-) Byzantine style and the patron's effort to attract masters from one of the northern Russian principalities, most likely Pskov, ${ }^{53}$ these paintings were not documented in the historical records. However, art history views the murals of the Chapel of the Holy Cross as a declaration of the continuity of the reigning Jagiellonian house. Moreover, the murals (inscribed monolingually in Cyrillic) showed that this house had a specific, albeit outdated, visual taste. Although the absence of records pertaining to the murals from 1470 might be due to a loss of documents rather than the absence of discussion, posterity has regarded this dynastic statement as worthy of survival: in contrast to all the other Byzantine wall paintings in the churches of Poland, those in the Chapel of the Holy Cross have never been plastered

53 The Pskov origins have been established by a stylistic analysis and circumstantial evidence, see RóżYckABryzek, Anna: Bizantyńsko-ruskie malowidta ścienne w kaplicy Świętokrzyskiej na Wawelu. Studia do dziejów Wawelu 3, 1968, pp. 175-293. The prevailing opinion based on stylistic and iconographic analyses suggests the painters belonged to the Pskov School of painting, see Ружитска-Брызек, Анна [i.e., RóżyскаBryzeк, Anna]: Росписи капелль Казимира Ягеллона на Вавеле. In: Художественна жизнь Пскова и искусство поздневизантийской эпохи. К 1100-летию Пскова. Ed. Мария А. Орлова. Moskva 2008, pp. 217-240. Recently, the alternatives of Polotsk and Smolensk have been suggested, see SzYNDLAREwICZ, Magdalena: Pochodzenie mistrzów fresków w Wawelskiej kaplicy Świętokrzyskiej - czy to na pewno Psków? Studenckie Zeszyty Naukowe 5/1, 2008, pp. 67-83. However, given the ruinous restoration of the paintings which caused enormous losses to the originals (ZALEwski, Władysław: Malowidto bizantynisko-ruskie. Historia konserwacji malowidet bizantyńskich (1470) w kaplicy Świętokrzyskiej w katedrze na Wawelu. Biuletyn Informacyjny Konserwatorów Dzieł Sztuki 9/3, 1998, pp. 2-15 and Mamoń, Agata: Malowidta bizantyńsko-ruskie w kaplicy Świętokrzyskiej katedry Wawelskiej. Budowa technologiczna, stan zachowania i postęowanie konserwatorskie na podstawie prac prowadzonych w latach 1998-2001, ibidem 14/1-2, 2003, pp. 74-85), the provenance of the painters could be established only if written evidence was found. 
over and despite significant alterations due to numerous repairs, reconstructions and restorations, have been visible for more than five centuries. ${ }^{54}$

The question of whether the tradition of a conscious archaism in the form of Byzantine murals was passed on by word of mouth in the Jagiellonian house is purely speculation $^{55}$ which cannot be substantiated by clear evidence. On the contrary, the first documented case of whitewashing over the Byzantine murals was under the orders of the Jagiellons: in 1594/5, Queen Anna Jagiellon (reign 1574-1598) ordered the rearrangement of the Chapel of the Nativity of the Virgin Mary into a monument to her late husband, King Stephan Bathory (reign 1576-1586). ${ }^{56}$ Following the queen's order, the court painter Kasper Kurcz (d. 1610) plastered over the walls of the chapel and decorated them with mannerist murals. The new interior of the chapel signalled the visual and dynastic end of Byzantine wall paintings. Paradoxically, the style that made Wladislas' II commissions so distinct was abandoned by the king's great-granddaughter, the first in the family widely and consistently styling herself with the Jagiellonian surname. ${ }^{57}$

\section{Concluding remarks}

The century of Byzantine murals in Lithuania and Poland reflects the changing attitudes in religious matters. Having functioned in the grand duchy as passive decoration in terms of religion, the paintings became a religious matter after the country's conversion and their "exportation" to the kingdom. They offered a place and opportunity for Catholic and Orthodox thinkers to express their attitudes towards heterodox patrons and display a confessional supremacy. The intensity of the debate correlates to the number of Byzantine paintings. The numerous commissions by Wladislas II prompts a search for iconographical nuances and religious statements. The single commission by Casimir IV might be regarded as a dynastic statement. The Byzantine murals had been introduced into the Kingdom of Poland on a royal whim due to their fondness of the style, and they retained this reputation for a century, but the style then disappeared earlier than the house which had brought these paintings into the new realm.

54 For the chronology of the repairs see Kruk, M. P.: Malowidta, p. 154.

55 On keeping the memory of individual Jagiellonian family members, see Borkowska, Urszula: Dynastia Jagiellonów w Polsce. Warszawa 2012, pp. 390-471.

56 Manoń, Agata: Problemi rekonstrukcji i aranżacji reliktów malowidet sciennych w kaplicy Mariackiej przy Katedrze Wawelskiej. Biuletyń Informacyjny Konserwatorów Dzieł Sztuki 20/1-4, 2009, pp. 74-81. For an overview of Anna Jagiellon's commission, see Fishinger, Andrzej: Przebudowa kaplicy Mariackiej w katedrze wawelskiej na mauzoleum krola Stefana Batorego. Studia do dziejów Wawelu 1, 1955, pp. 349-366.

57 On the usage of the Jagiellonian name, see Nowakowska, Natalia - Afanasyev, Ilya - Kuzmová, Stanislava -Mickūnaité, Giedrè - Nirranen, Susanna - Zupka, Dušan: Dynasty in the Making. The Idea of the Jagiellonians, c. 1385-1660 (forthcoming). 


\section{Náboženská diskuze a vizuální kompromis: interpretace byzantských nástěnných maleb na Litvě a v Polsku}

Na konci 14. století byly obytné interiéry velkoknížecích hradů na Litvě často zdobeny freskami v byzantském stylu. Tyto fresky, jež se podobají soudobým nástěnným malbám v Pskově a Tveru, dokazují, že umění dokázalo překročit náboženskou hranici a pravoslavní umělci pracovali na zakázkách pohanských zadavatelů. Byzantský styl dekorace interiérů zůstal mezi litevskými elitami populární i po přestupu země k latinské podobě křest̉anství v roce 1387.

Rozbor byzantských nástěnných maleb zachovaných v polských a litevských kostelech naznačuje, že se jejich provedení přizpo̊sobovalo náboženskému přesvědčení katolických patronů a zadavatelů, stejně jako tomu bylo u pravoslavných pánů. Malby, které respektovaly principy katolické ikonografie a doplňovaly latinské nápisy, příznačně zdobily chrámové prostory, kam příchozí jen obtížně dohlédli. Pravoslavní ikonopisci naproti tomu při malbě katolických vládců vynechávali svatozáře, jež byly charakteristickým znakem byzantských a také ruských vládců. Do nástěnných maleb se tedy takto promítly konfesní konflikty první poloviny 15. století.

Velmi zajímavým př́kladem využití fresek v byzantském stylu je výzdoba kaple sv. Kříže v krakovské katedrále, kterou Kazimír IV. nechal realizovat pravoslavnými umělci v roce 1470. Nesporně právem je tento jeho počin vnímán spíše jako dynastický než náboženský. Cílem studie je ukázat, že architektura kaple a její nástěnné malby byly zvoleny tak, aby ilustrovaly kontinuitu jagellonského domu. Přitom je určitým paradoxem, že královna Anna Jagellonská, poslední příslušnice jagellonského rodu, nařizovala ničení byzantských fresek, které nechal v kapli Narození Panny Marie ztvárnit její pradědeček, král Vladislavem II. Jagello. 

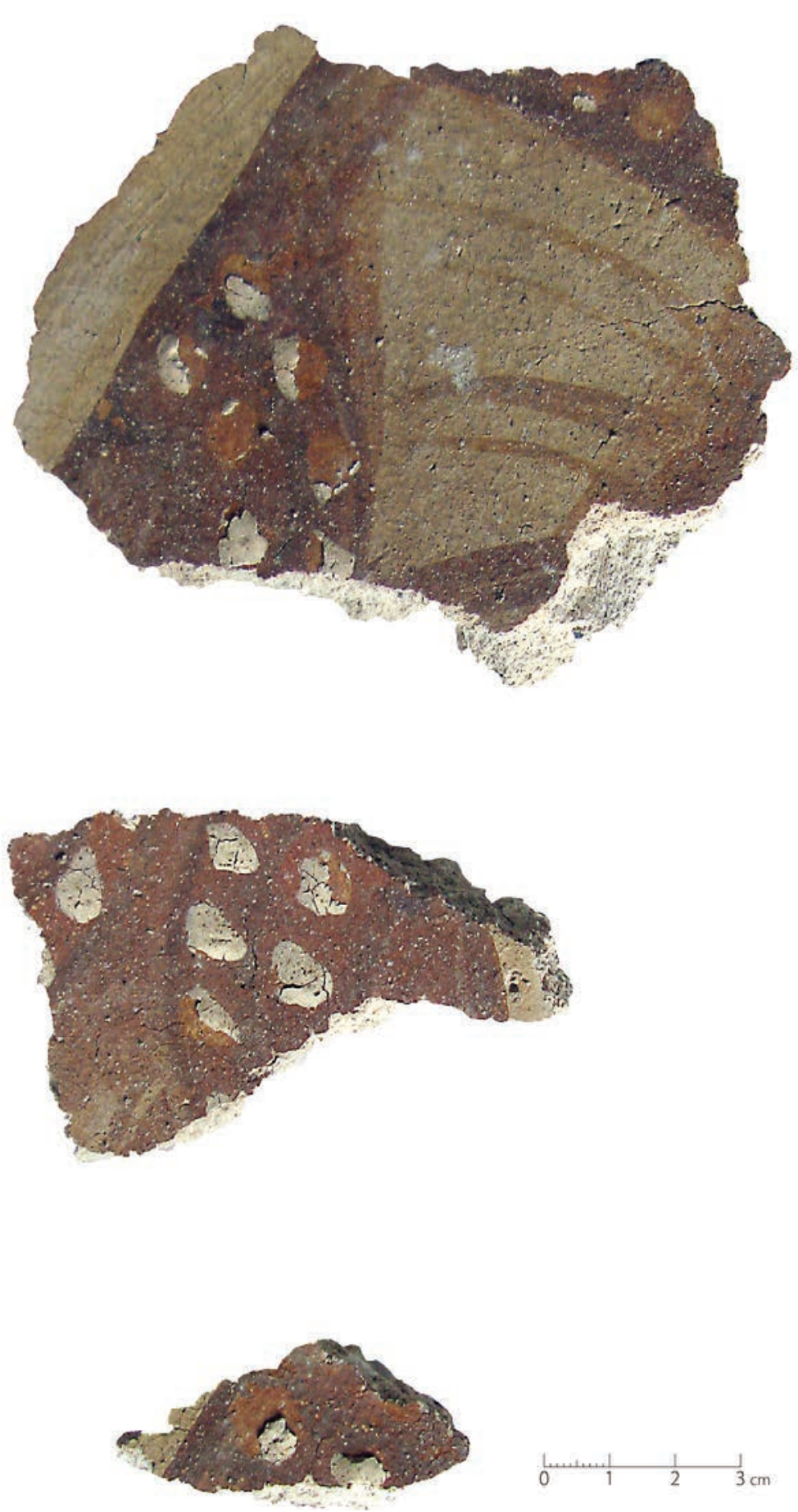

1. Kreva: fragments with painted ornament finished with thick dots of white paint excavated in 2012. Photo: Giedrè Mickūnaitè, 2014. 

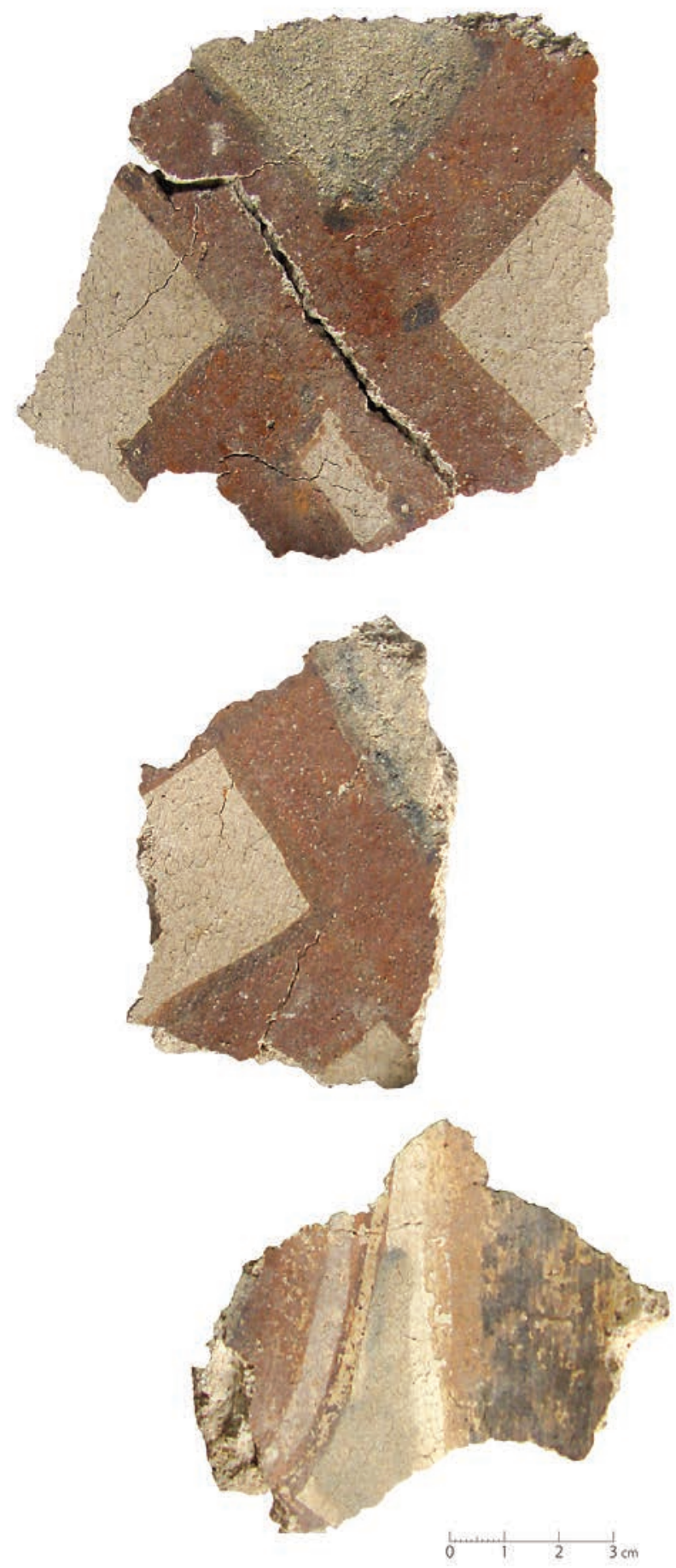

2. Kreva: fragments with painted plaited ornaments excavated in 1988.

Photo: Giedrè Mickūnaitè, 2013. 


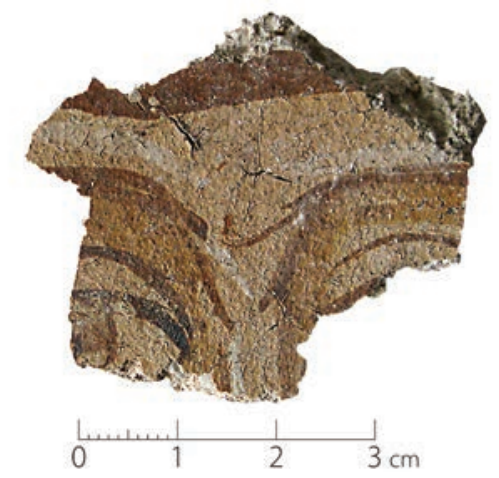

3. Kreva: fragment with remnant of face excavated in 2012. Photo: Giedrè Mickūnaitè, 2014.

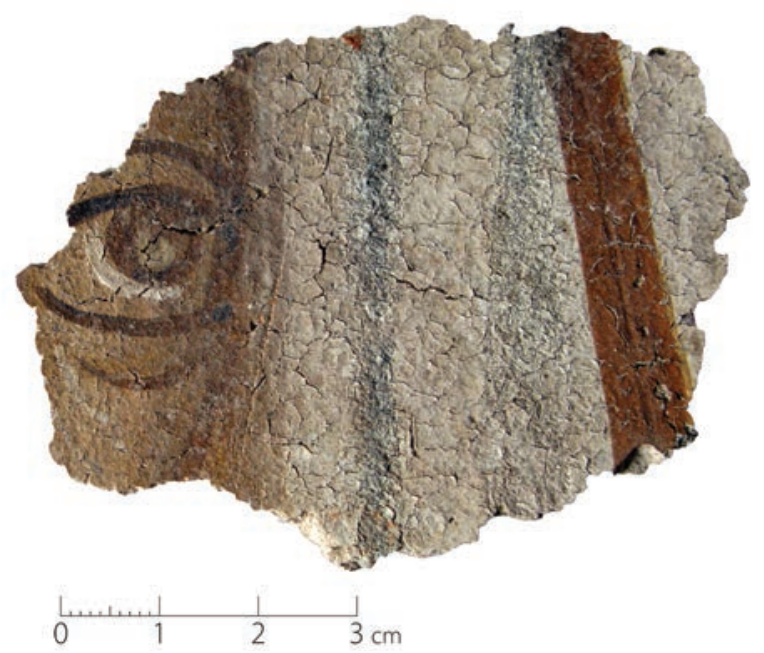

4. Kreva: fragment with remnant of face excavated in 2012. Photo: Giedrè Mickūnaitè, 2014.

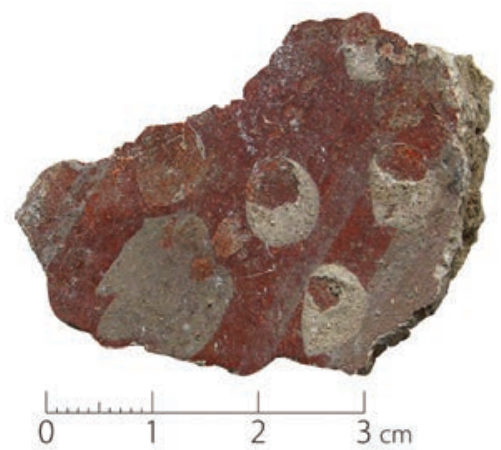

5. Medininkai: fragment with painted ornament finished with thick dots of white paint excavated 1994. Photo: Giedrè Mickūnaitè, 2014. 

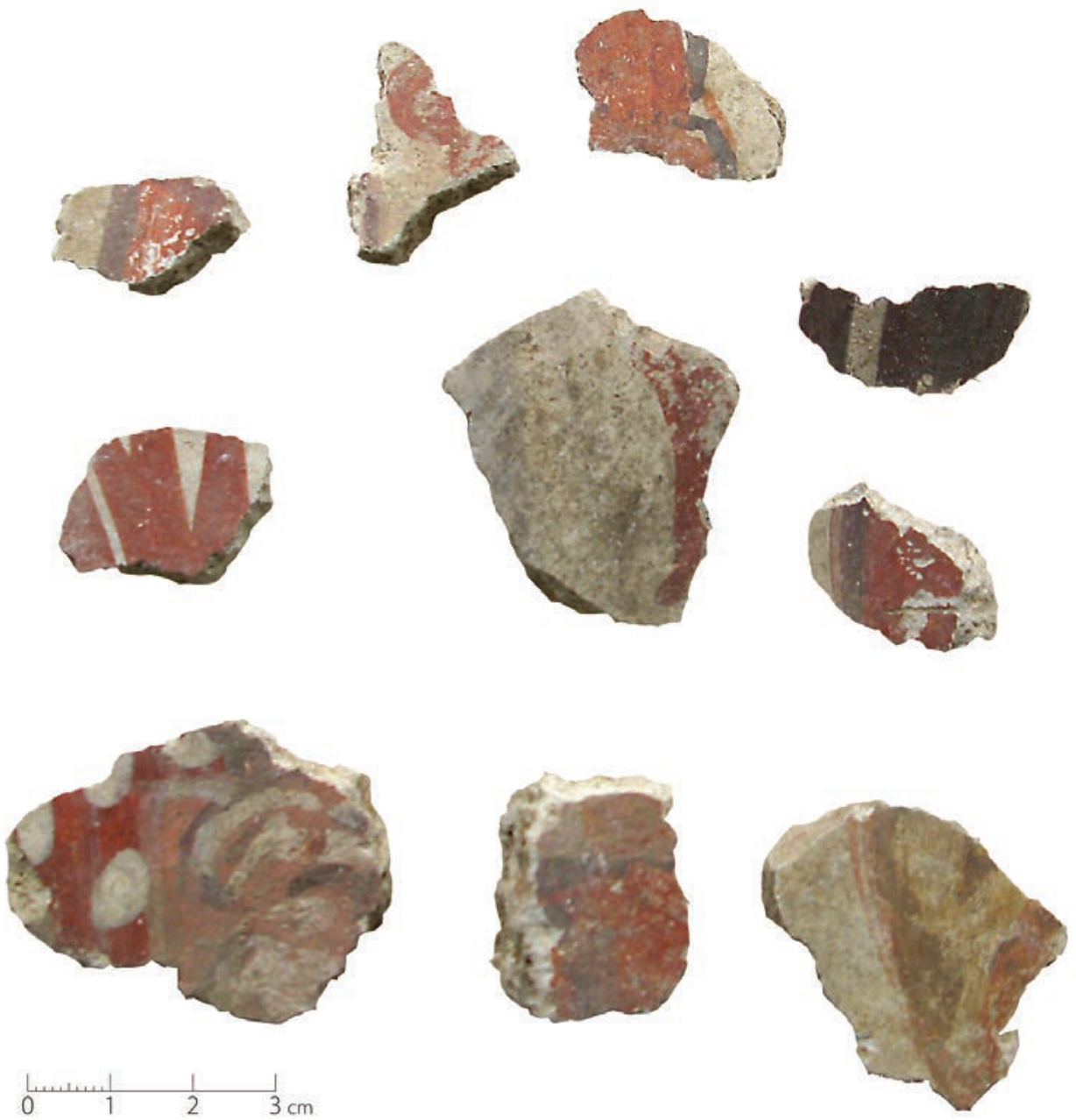

6. Medininkai: fragment with painted ornaments excavated in 1994. Photo: Giedre Mickūnaitè, 2014. 


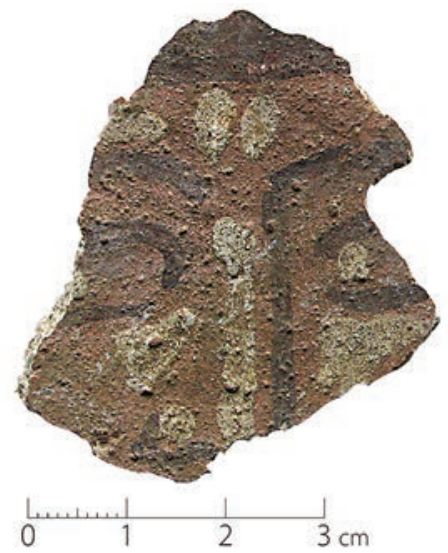

7. Medininkai: fragment of face excavated in 1994. Photo: Giedrè Mickūnaitè, 2014.

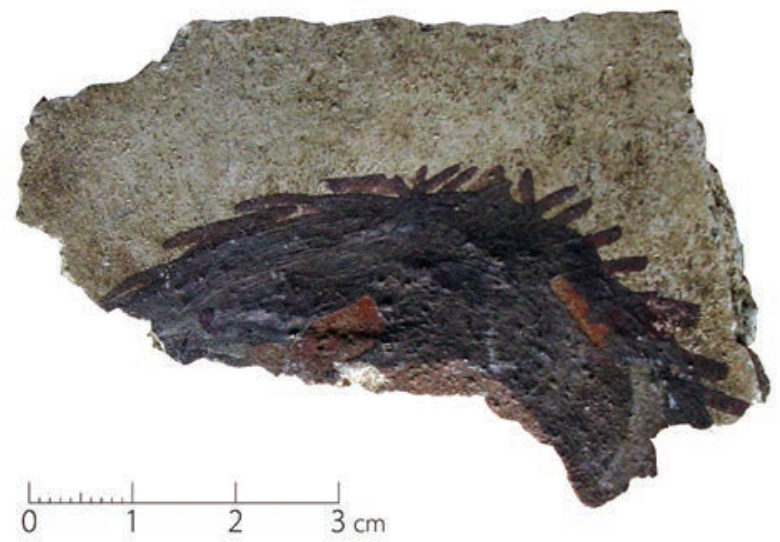

8. Medininkai: fragment with human hair(?) excavated in 1994. Photo: Giedrè Mickūnaitè, 2014.

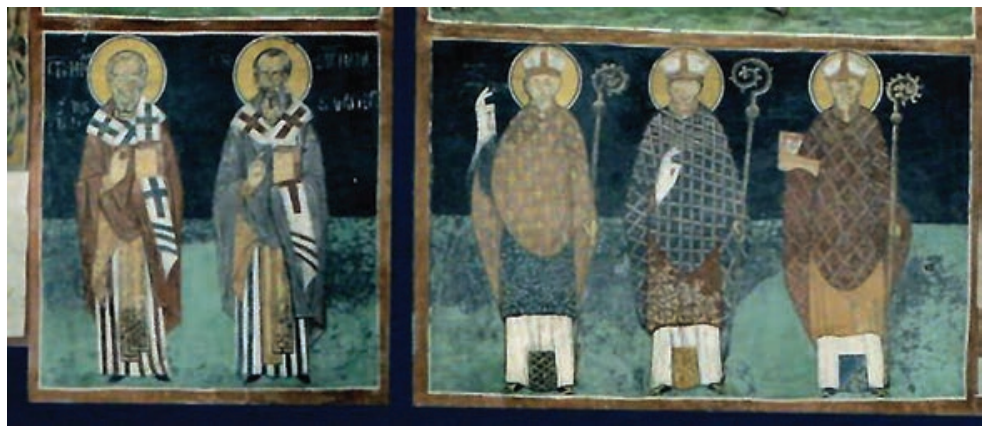

9. Sts Nicolas and Basil the Great and three saint bishops in Catholic vestments, wall paintings on the southern wall of the apse of the Cathedral of Sandomierz, 1402-1416. After Bazylika Katedralna pw. Narodzenia Najświętszej Maryi Panny, p. 83. 


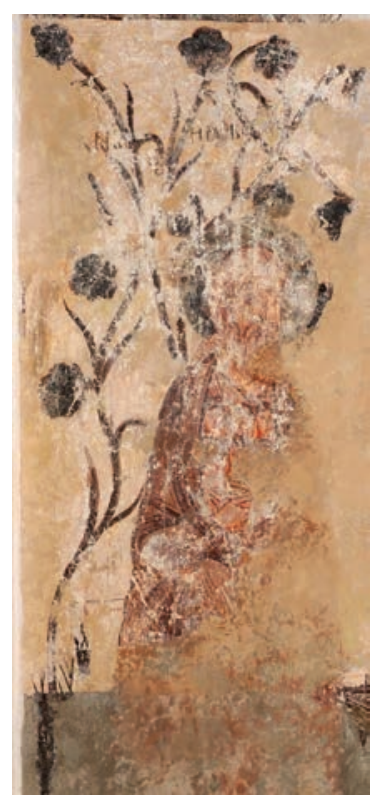

10. Patriarch Jacob under a tree of paradise painted on the western wall of the Trakai church, ca. 1419. Photo: Kęstutis Stoškus, 2008.

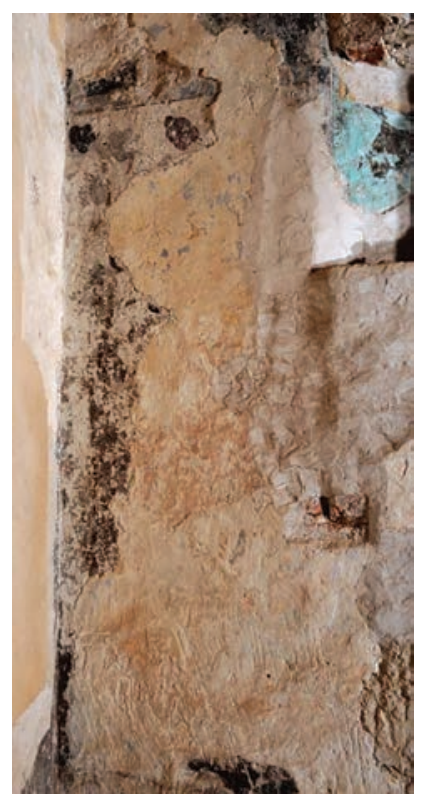

11. A tree of paradise painted on the northern wall of the Trakai church, ca. 1419. Photo: Kęstutis Stoškus, 2008.

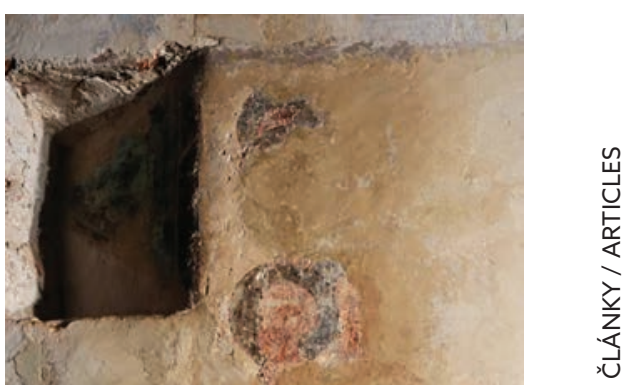

12. Procession of the elect. painted on the northern wall of the Trakai church, ca. 1419. Photo: Kęstutis Stoškus, 2008. 


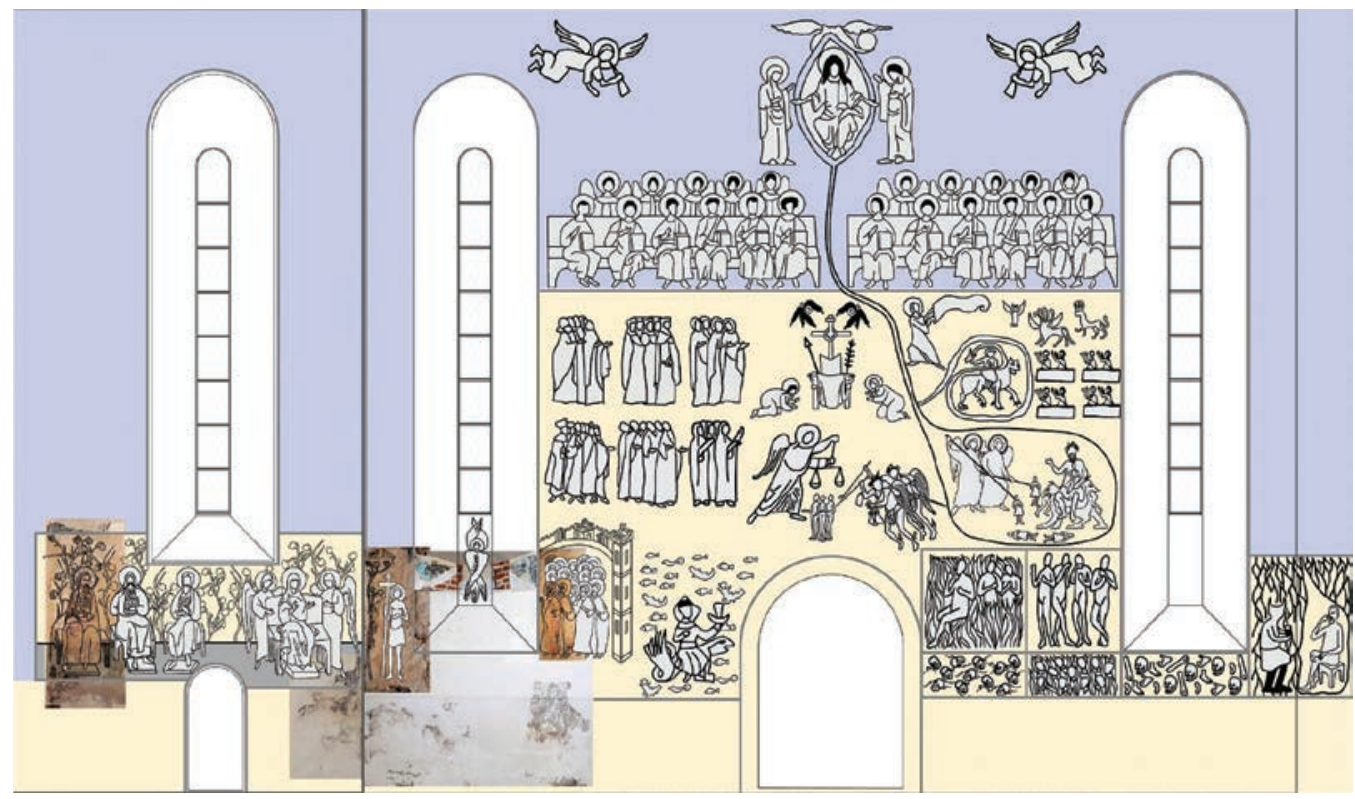

13. The Last Judgment, hypothetical reconstruction of the iconography of the wall paintngs, northern, western and eastern walls of the Trakai church. Drawing: Rūta Mickienè, 2013. 


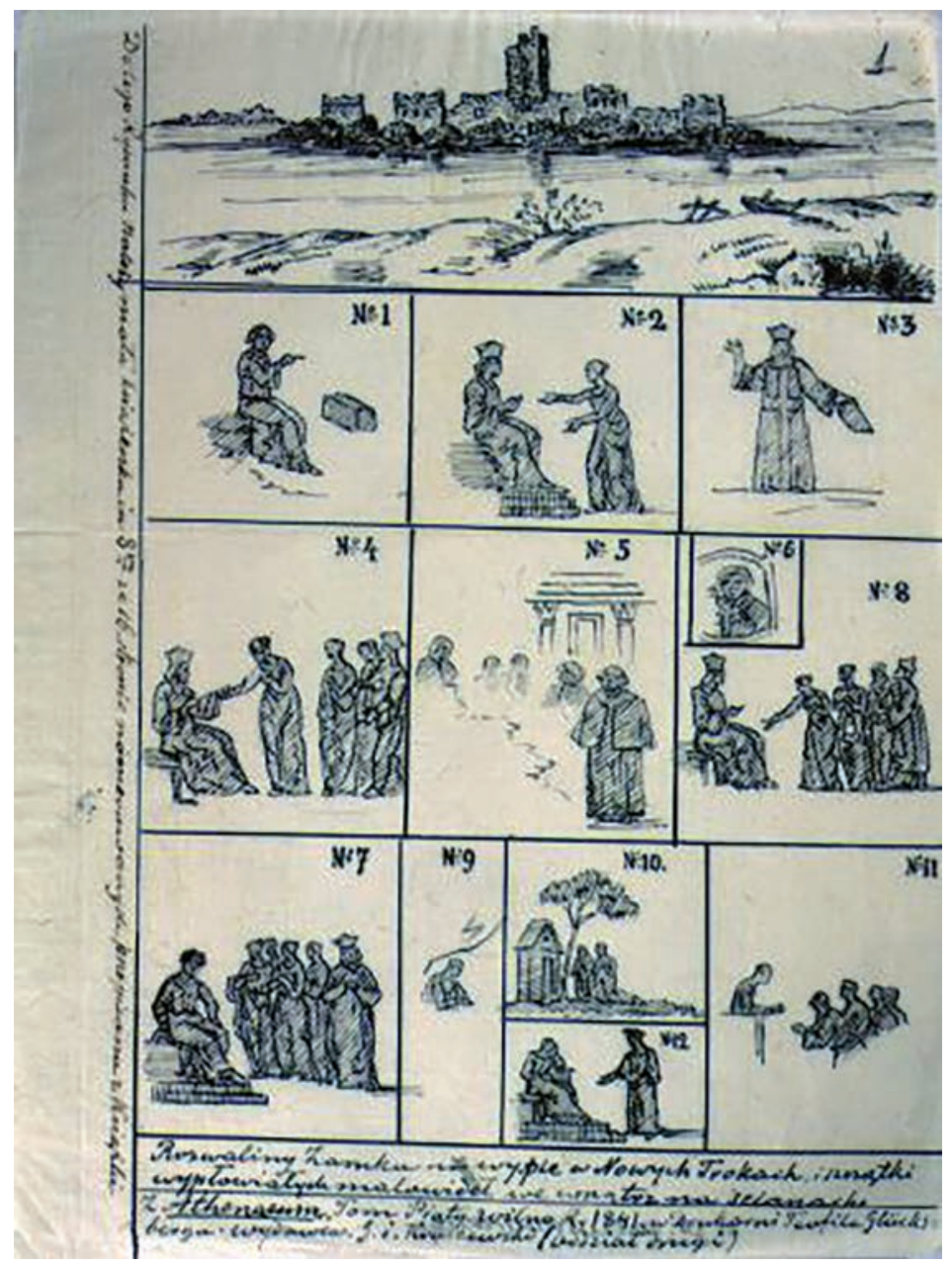

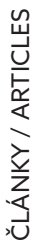

14. Wincenty Smokowski, Fragments of wall paintings in the palace of the Trakai Island Castle. Project of the lithograph, Indian ink on paper, 1841. Lithuanian State Historical Archives, F. 1135, B. 19, s.v. 74 , fol. 1. 


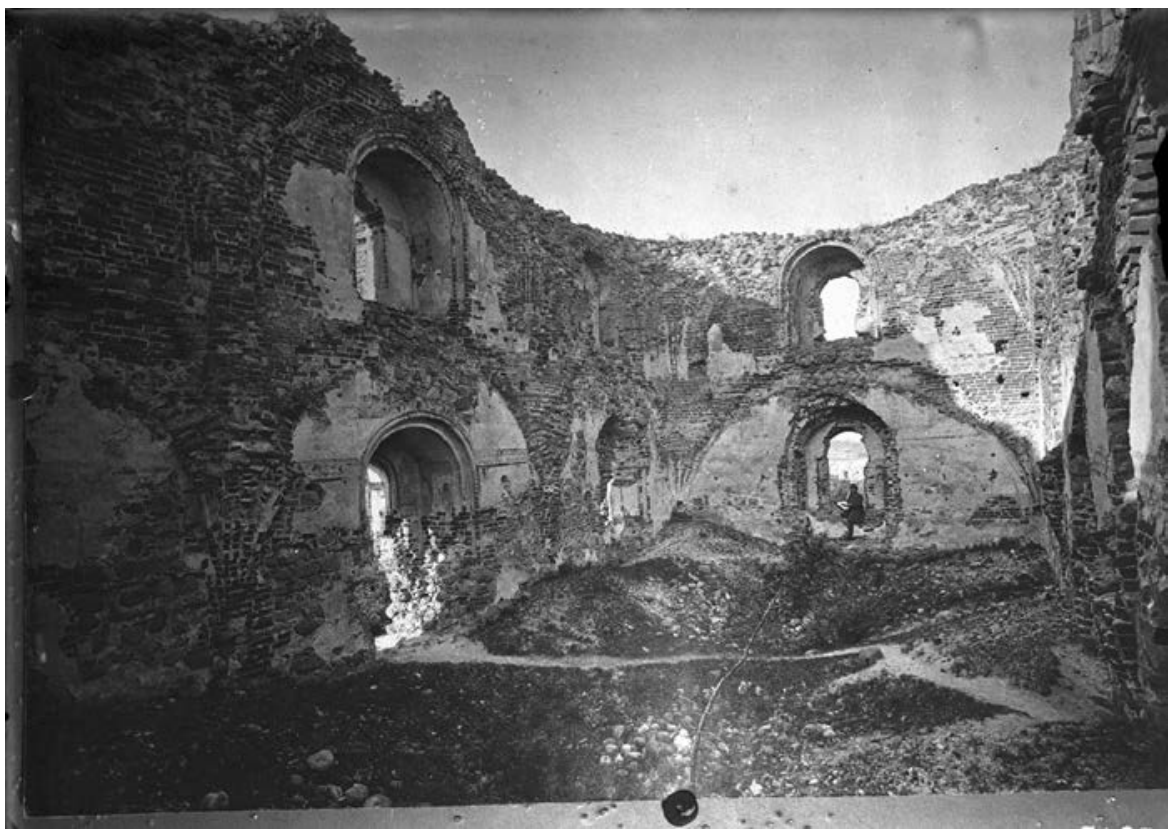

15. Southern wing of the palace of Trakai Island Castle, 1893. Phoptograph from the collection of Towarzystwo Straży Kresowej,' Institute of Art of the Polish Academy of Sciences, neg. no. 3213.

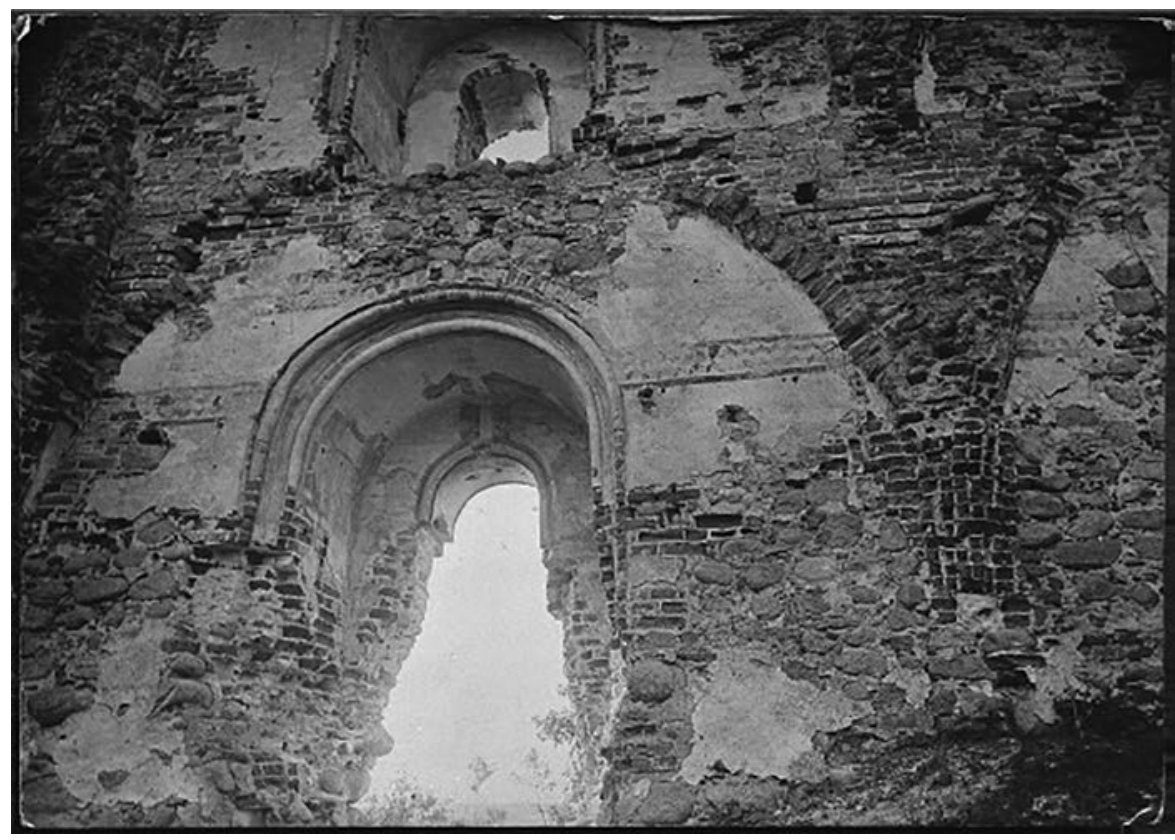

16. Stanisław Filibert Fleury, Wall paintings in the audience hall of the palace of the Trakai Island Castle, 1888. Institute of Art of the Polish Academy of Sciences, neg. no. 142764. 


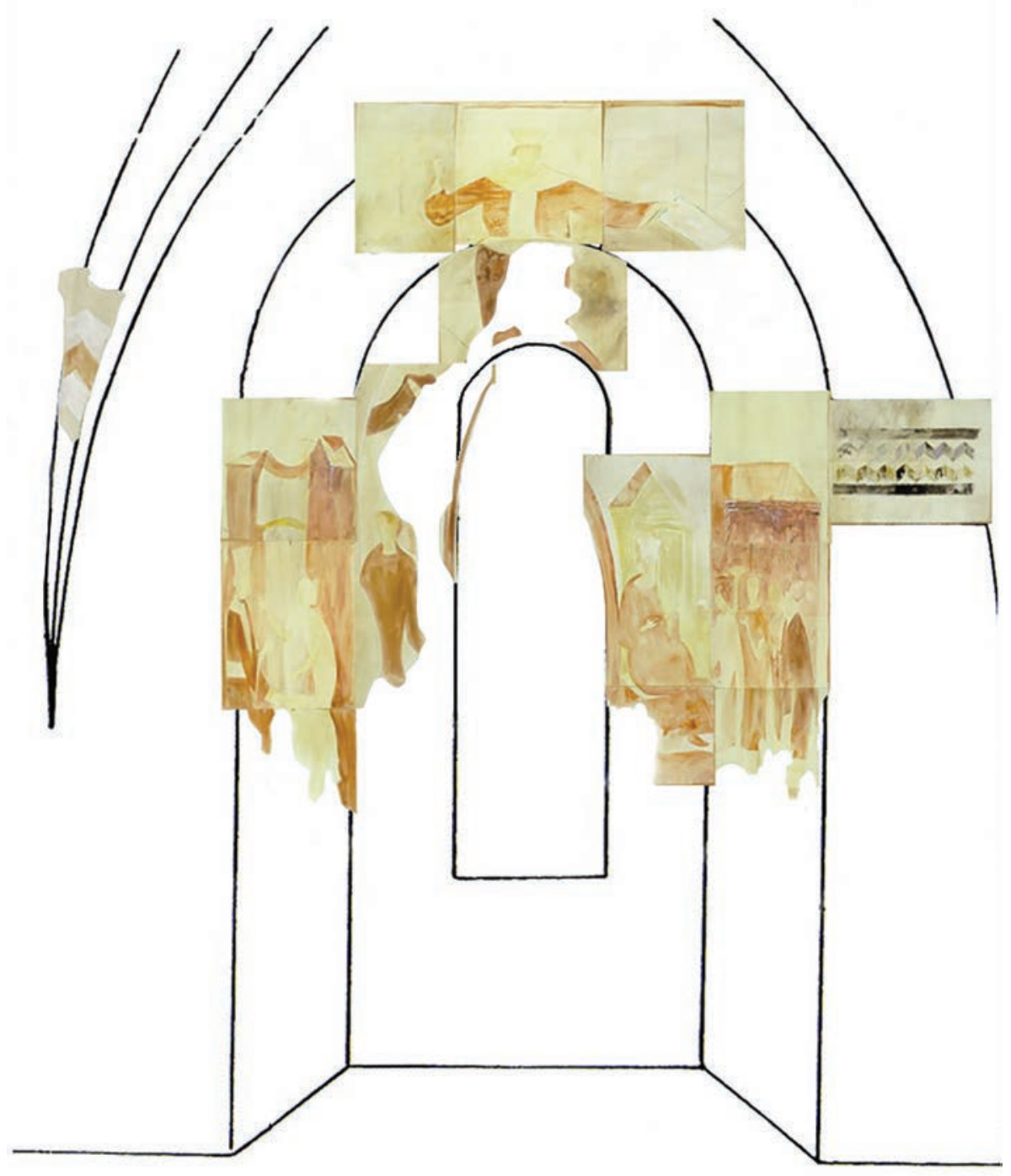

17. Jerzy Hoppen, Wall paintings in the palace of Trakai Island Castle, central niche of the audience hall (water colour on paper), 1932. Photo: Virginijus Usinavičius and Zenonas Nekrošius, 1997; arrangement: Giedre Mickūnaitè, Lithuanian State Historical Archives, F. 1135, B. 12. 
Religious Debate and Visual Compromise: Interpreting Byzantine Murals in Lithuania ...

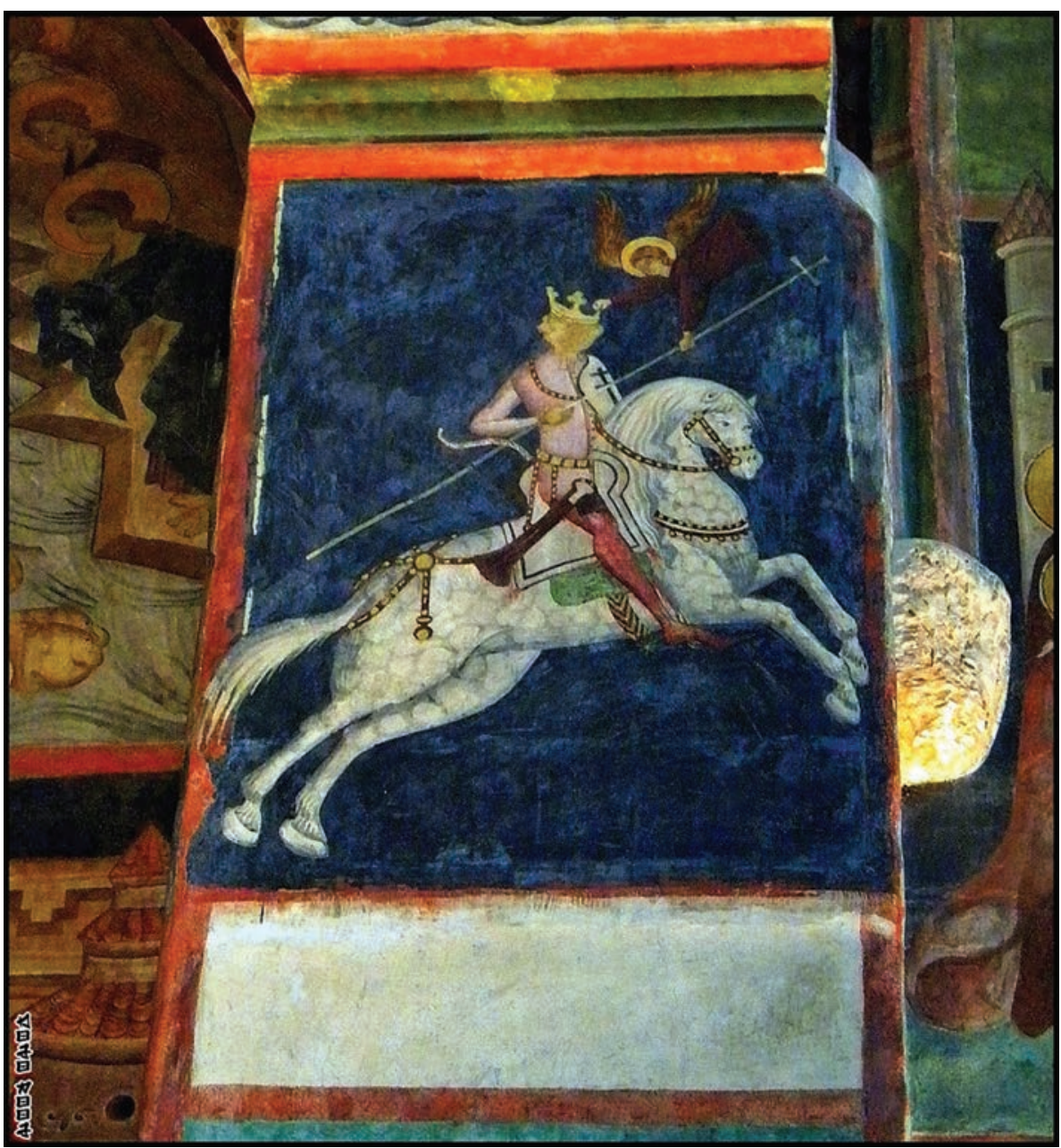

18. Master Andrew and assistants, Wladislas II Jogaila on horseback, wall painting in the Chapel of Holy Trinity in Lublin castle, 1418. Available at: https://www. historiaposzukaj.pl/wie dza,architektura,321,architektura_kaplica_trojcy_swietej_na_zamku_w_lublinie.html 


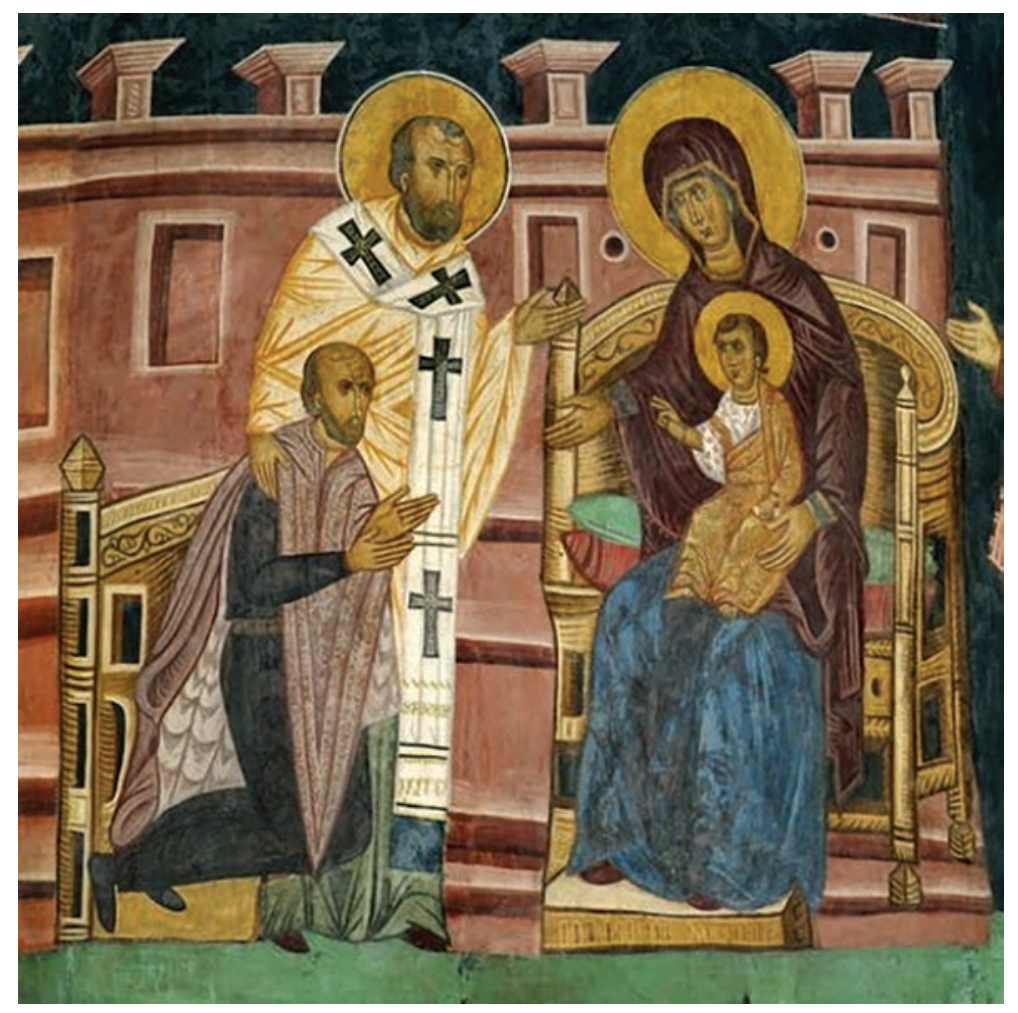

19. Master Andrew and assistants, Wladislas II Jogaila kneeling before the Virgin and Child, wall painting in the Chapel of Holy Trinity in Lublin castle, 1418. Available at: http://teatrnn.pl/ leksykon/artykuly/freski-w-kaplicy-trojcy-swietej/\#malowidla 
Religious Debate and Visual Compromise: Interpreting Byzantine Murals in Lithuania ...

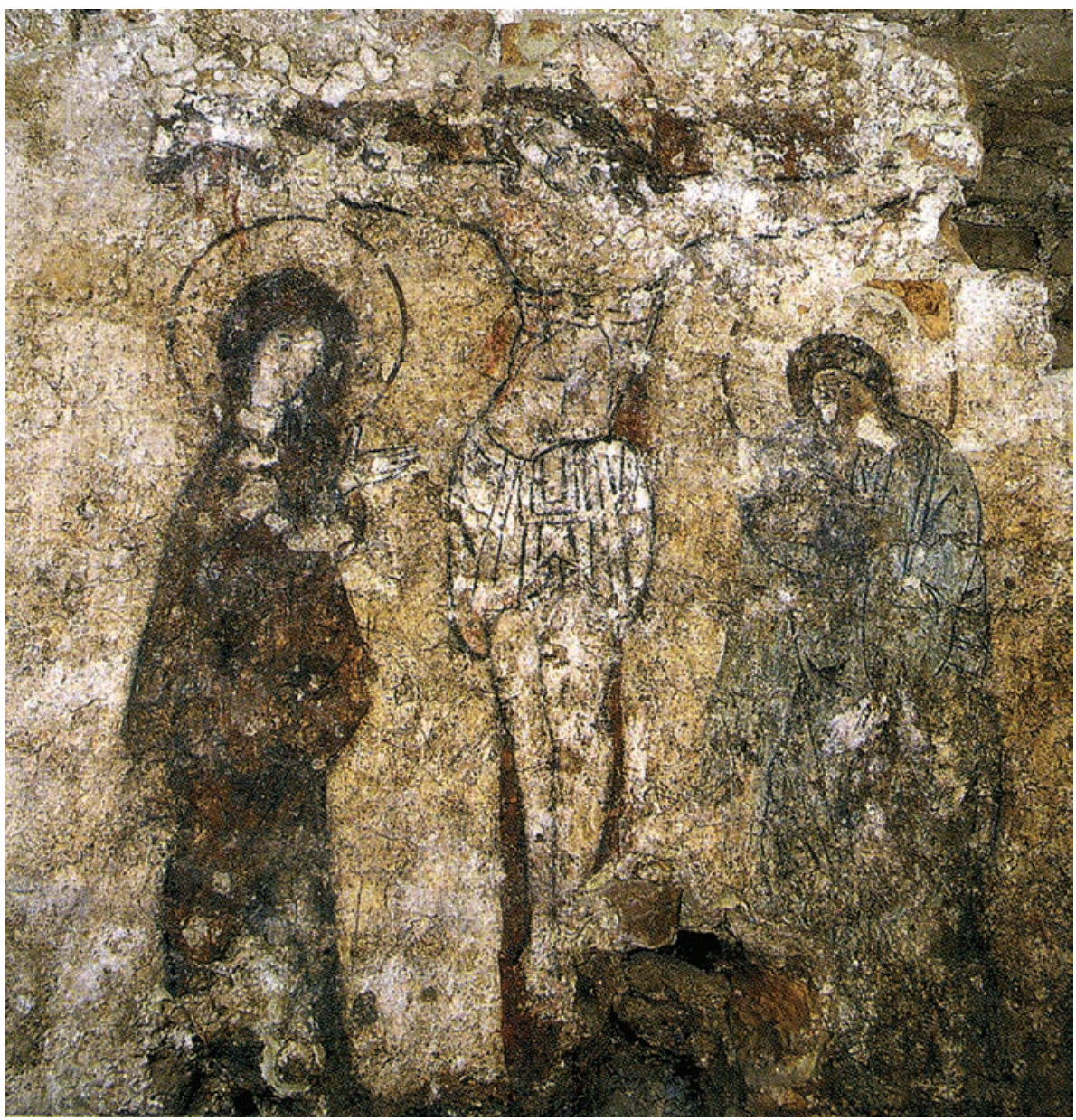

20. Crucifixion with the Virgin Mary and St. John the Evangelist, wall painting, Vilnius Cathedral, ca. 1400. Photo courtesy Elektroninès leidybos namai. 


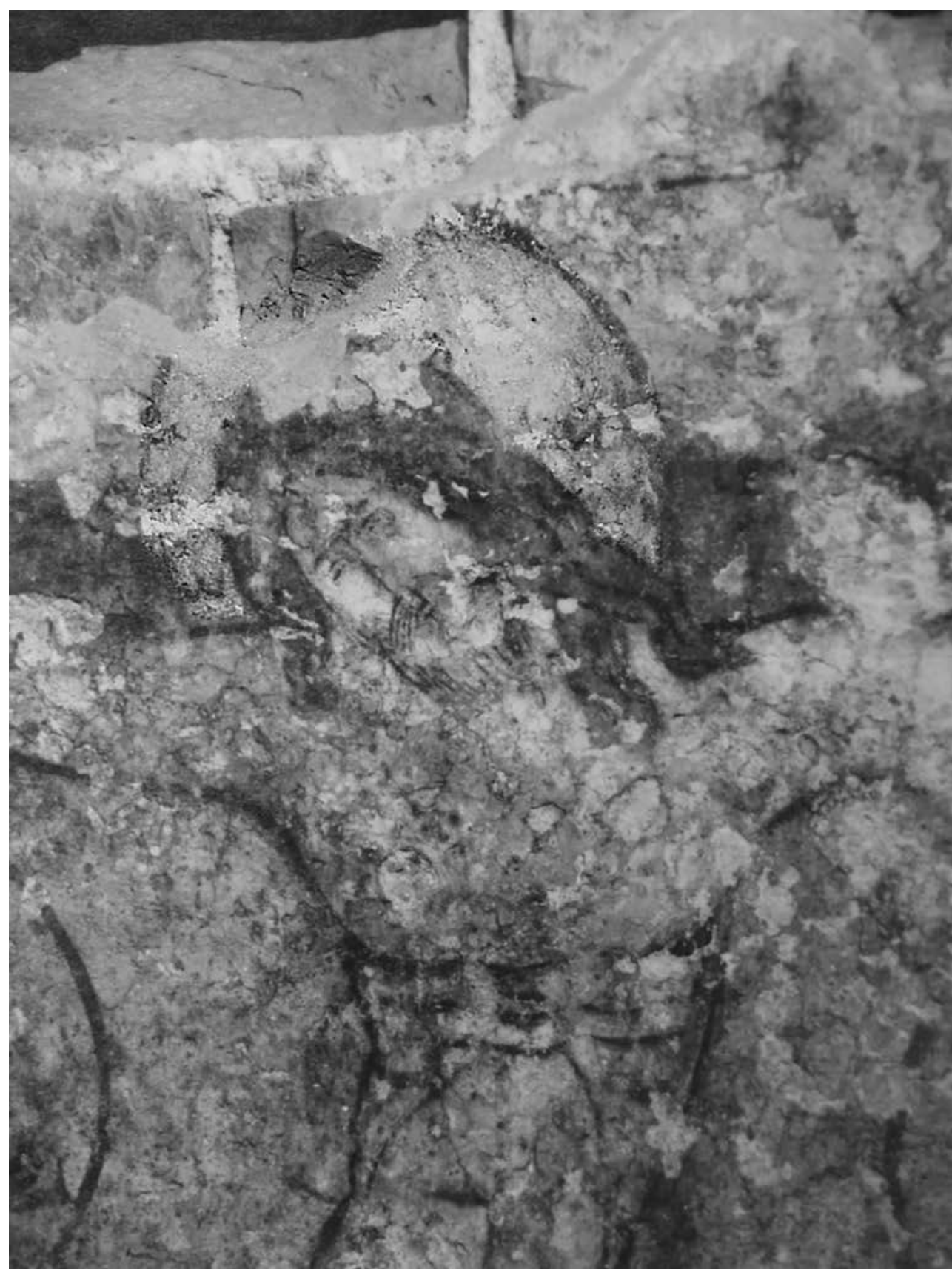

21. Figure with the Crucified, fragment of the composition 'Crucifixion with the Virgin Mary and St. John the Evangelist', Vilnius Cathedral, ca. 1400. Photo: Romualdas Sabataitis, 1985. Characters ' $\omega$ ' and ' $u$ ' overdrawn by Giedrè Mickūnaitè. 
